\title{
Multilateral Creeping Coastal State Jurisdiction and the BBNJ Negotiations
}

\author{
ErikJ. Molenaar \\ Netherlands Institute for the Law of the Sea, Utrecht University, \\ Utrecht, The Netherlands \\ e.j.molenaar@uu.nl
}

\begin{abstract}
The interrelated notions of adjacency and creeping coastal State jurisdiction have been a key driver in the historical development of the international law of the sea. Although the United Nations Convention on the Law of the Sea (LOSC) managed to bring an end to unilateral coastal State claims to new and broader maritime zones, creeping coastal State jurisdiction per se continued, both unilaterally and multilaterally. This article focuses on so-called multilateral creeping coastal State jurisdiction - which originates predominantly from intergovernmental bodies - and in particular on the role of this phenomenon in the currently ongoing negotiations on an agreement on marine biodiversity beyond national jurisdiction under the LOSC (ввNJ Agreement). The article contains a detailed analysis of the relevant provisions in the draft в BNJ Agreement of 18 November 2019 and subsequent text proposals by delegations, in light of the historical development of the law of the sea.
\end{abstract}

\section{Keywords}

jurisdiction - coastal State - areas beyond national jurisdiction - adjacency subjacency - superjacency - transboundary 


\section{Introduction $^{1}$}

The phenomenon of 'creeping coastal State jurisdiction' has been one of the principal drivers in the development of the modern international law of the sea. ${ }^{2}$ Before World War II, this domain was largely built on the freedom of the high seas and the associated primacy of flag State jurisdiction postulated by Hugo de Groot (Grotius). Soon after World War II, however, technological developments and scarcity of resources in particular led coastal States to unilaterally claim exclusive access and jurisdiction over living and non-living resources in new and increasingly broader maritime zones adjacent to their coasts. This process was largely halted by the 1982 LOSC, ${ }^{3}$ which recognised the sovereignty, sovereign rights and jurisdiction of coastal States in their broader and new maritime zones (e.g., the exclusive economic zone (EEZ)).

However, creeping coastal State jurisdiction is by no means a relic of the past and continues to be relevant today. It is argued that it manifests itself in two ways: unilaterally and multilaterally. State practice on marine capture fisheries in the EEZ, leading to the so-called 'thickening' of coastal State jurisdiction, ${ }^{4}$ could be regarded as an example of the first form. Some of this State practice has been upheld by the International Tribunal for the Law of the Sea (ITLOS) in its judgment in the Virginia $G$ case. ${ }^{5}$ This article, however, is limited to the second form - multilateral creeping coastal State jurisdiction - which

1 The author is very grateful for comments received from Liesbeth Lijnzaad, Philipp Nickels and an anonymous reviewer on an earlier version of this article.

2 See RY Jennings, 'A changing international law of the sea' (1972) 31 Cambridge Law Journal 32-49, at pp. 34-36; B Kwiatkowska, 'Creeping jurisdiction beyond 200 miles in the light of the 1982 Law of the Sea Convention and State practice' (1991) 22 Ocean Development and International Law (ODIL) 153-187; E Franckx, 'The 200-mile limit: Between creeping jurisdiction and creeping common heritage' (2005) 48 German Yearbook of International Law 117-149; BH Oxman, 'The territorial temptation: A siren song at sea' (2006) 100 American Journal of International Law $830-851$.

3 United Nations Convention on the Law of the Sea (Montego Bay, 10 December 1982, in force 16 November 1994) 1833 UNTS 396 (LOSC).

4 See C Goodman, The Nature and Extent of Coastal State Jurisdiction over Living Resources in the Exclusive Economic Zone (PhD manuscript of February 2019, Australian National University); DR Rothwell, AG Oude Elferink, KN Scott and T Stephens, 'Charting the future for the law of the sea' in DR Rothwell, AG Oude Elferink, KN Scott and T Stephens (eds), The Oxford Handbook of the Law of the Sea (Oxford University Press, Oxford, 2015) 888-912, at p. 892.

5 The $M / V^{\prime}$ Virginia G' case (Panama v. Guinea-Bissau), Judgment of 14 April 2014, ITLOS Reports 2014 , p. 4, at paras $217-218,222$. It is acknowledged that, as international agreements such as those mentioned by the Tribunal in para 216 are likely to have led to at least some State practice, the origin of such State practice is not truly unilateral. 
originates predominantly from intergovernmental bodies. ${ }^{6}$ An example is the coastal State jurisdiction beyond the outer limit of the territorial sea relating to underwater cultural heritage created by the 2001 Underwater Cultural Heritage Convention ${ }^{7}$ adopted under the auspices of the United Nations Educational, Scientific and Cultural Organization (UNESCO). ${ }^{8}$

The focus of this article is mainly on the role of multilateral creeping coastal State jurisdiction in the currently ongoing negotiations under the auspices of the United Nations General Assembly (UNGA) on a new B BNJ Agreement under the LOSC (BBNJ negotiations). ${ }^{9}$ The analysis will, inter alia, cover the most recent draft text of the BBNJ Agreement dated 18 November 2019 (further: First Draft). ${ }^{10}$ This draft was tabled for the fourth substantive session of the вВNJ negotiations, which was originally scheduled for 23 March - 3 April 2020 but was postponed without a new date due to the coronavirus disease 2019. ${ }^{11}$

6 For the purpose of this article, the term bodies is understood to comprise intergovernmental organisations and decision-making bodies such as the Meeting of the Parties (MOP) or Conference of the Parties (СOP) established under international legally binding instruments. Multilateral creeping coastal State jurisdiction could also originate from international legally binding agreements negotiated and adopted by an ( ad hoc) group of States outside the auspices of an intergovernmental body.

7 Convention on the Protection of the Underwater Cultural Heritage (Paris, 1 November 2001, in force 2 January 2009) 2562 UNTS 3. See in particular Arts 9 and 10.

8 Other examples are given in the subsection 'Post-UnCLOS III'.

9 Established by United Nations General Assembly (UNGA) Res 72/249 (24 December 2017) International legally binding instrument under the United Nations Convention on the Law of the Sea on conservation and sustainable use of marine biological diversity of areas beyond national jurisdiction, UN Doc A/RES/72/249. All formal documents on the BBNJ negotiations are available at https://www.un.org/bbnj/; all websites accessed 16 November 2020. For in-depth analyses on various aspects of the ввNJ negotiations see D Freestone (ed), Conserving Biodiversity in Areas beyond National Jurisdiction (Brill/ Nijhoff, Leiden, 2019).

10 UNGA, Revised draft text of an agreement under the United Nations Convention on the Law of the Sea on conservation and sustainable use of marine biological diversity of areas beyond national jurisdiction, Doc. A/CONF.232/2020/3, 18 November 2019 [First Draft]. The First Draft builds on the 'Zero Draft' dated 17 May 2019 (UNGA, Draft text of an agreement under the United Nations Convention on the Law of the Sea on conservation and sustainable use of marine biological diversity of areas beyond national jurisdiction, UN Doc. A/CONF.232/2019/6, 17 May 2019). See also the un-numbered document of 27 November 2019 that highlights the changes to the Zero Draft. The terms Zero and First Draft are also used by L Lijnzaad, 'Dispute settlement for marine biodiversity beyond national jurisdiction: Not an afterthought' in H Ruiz Fabri, E Franckx, M Benatar and T Meshel (eds), A Bridge over Troubled Waters: Dispute Resolution in the Law of International Watercourse and the Law of the Sea (Brill/Nijhoff, Leiden, 2020) 147-182.

11 UNGA, Draft decision submitted by the President of the General Assembly, Un Doc. A/74/L.41, 9 March 2020. 
Account will also be taken of the textual proposals to the First Draft submitted by 20 February 2020 by delegations in the BBNJ negotiations. ${ }^{12}$

The mandate of the ввNJ negotiations is the conservation and sustainable use of marine biological diversity in 'areas beyond national jurisdiction' (ABNJ)..$^{13}$ These areas consist of the high seas (the water column) and the 'Area' (international seabed). ${ }^{14}$ Both lie seaward of the outer limits of coastal State maritime zones, namely, EEZs or other 200 nautical mile (M) maritime zones derived from EEZs (e.g., exclusive fishery zones (EFZs)) - if proclaimed - and/ or continental shelves. These and all other coastal State maritime zones namely, internal waters, archipelagic waters, the territorial sea and the contiguous zone - are in this article collectively referred to as 'areas within national jurisdiction' (AWNJ).

As will become clear further below, several delegations in the BBNJ negotiations have asserted special roles, interests and/or rights for coastal States with respect to $\mathrm{ABNJ}$ adjacent to their maritime zones. Assertions based on the notion of 'adjacency' are primarily made with two 'horizontal' scenarios in mind; namely, the waters of the high seas and EEZs, and the seabed of the continental shelf and the Area. However, there are also two 'vertical' scenarios, in which high seas waters lie above the continental shelf. The first arises when continental shelves extend beyond $200 \mathrm{M}$; also called 'outer' continental shelves. The second arises when coastal States have, for various reasons, not proclaimed EEZs or other 200 M maritime zones, for instance many Mediterranean Sea coastal States. Such States have a clear interest in safeguarding the sovereign

12 A document dated 15 April 2020 containing an article-by-article compilation of these textual proposals [Compiled Textual Proposals Fourth BBNJ Session] is available at https://www.un.org/bbnj/.

13 First Draft (n 10), Articles 2, 3(1).

14 Whereas the Area is defined in Article $1(1)(1)$ of the LOSC (n 3) as 'the seabed and ocean floor and subsoil thereof, beyond the limits of national jurisdiction', the LOSC contains no definition of the high seas. The purpose of Article 86 of the LOSC is, rather, to clarify the geographical scope of application of the high seas regime. Note the phrases 'on the bed of the high seas' in Article 112(1) and 'beneath the high seas' in Articles 113 and 114, which appear to be contradictory. Article 1(4) of the Zero and First Drafts defines ABNJ as 'the high seas and the Area'. This definition does not exclude a vertical overlap between the high seas and the Area similar to, for instance, the vertical overlap between the EEZ and the continental shelf pursuant to Article 58(3) of the Losc. As indicated in the main text accompanying this note, however, the high seas is for the purpose of this article defined as the water column and thereby does not overlap vertically with the Area. See also the proposal by the International Union for Conservation of Nature (IUCN) to replace the definition of ABNJ in Article 1(4) of the First Draft with the text 'include the high seas and its superjacent airspace, and the Area' (Compiled Textual Proposals Fourth BBNJ Session (n 12), at p. 21). 
rights, jurisdiction and other rights related to these maritime zones to which they are entitled under the LOSC and customary international law, but that they have not exercised so far. ${ }^{15}$ Similar interests exist in cases where coastal States have not been able to establish final and binding outer limits of their 200 M maritime zones or continental shelves. ${ }^{16}$

This article will often use the terms adjacent and adjacency in a generic sense, comprising horizontal as well as vertical scenarios. Where differentiation is necessary, however, the terms adjacent and adjacency are used for horizontal scenarios and the terms superjacent, superjacency, subjacent ${ }^{17}$ and subjacency for vertical scenarios.

The article is structured as follows. The next section provides an overview of the historical development of the law of the sea. This is followed by the sections entitled 'Adjacency, Superjacency, Subjacency and ABNJ in the LOSC and the Fish Stocks Agreement' and 'Multilateral Creeping Coastal State Jurisdiction and the ввNJ Negotiations'. The last section is devoted to conclusions.

\section{Historical Development of the Law of the Sea}

\section{From Classical Antiquity until the End of World War II}

Adjacency has been a key basis and rationale for State authority at sea since at least the era of classical antiquity. The Romans, for instance, called the Mediterranean Sea Mare Nostrum (Our Sea) and at one time asserted what may be characterised as sovereignty over it. ${ }^{18}$ Similar assertions over adjacent

15 See Articles 4(2) - in particular the words 'within and beyond' - and 15(5) of the First Draft; both reproduced in their entirety in subsections 'Preamble and General Provisions' and 'Measures such as Aвмтs, including M PAs'. As regards the Mediterranean Sea, see also Article 9 of the Protocol concerning Specially Protected Areas and Biological Diversity in the Mediterranean (Barcelona, 10 June 1995, in force 12 December 1999; available at http:// www.unepmap.org).

16 See also J Mossop and C Schofield, 'Adjacency and due regard: The role of coastal States in the BBNJ treaty' (2020) 122 Marine Policy 103877 , at p. 4.

17 This term is, inter alia, used in OSPAR Agreement 2019-og 'General consultation procedures for establishing Marine Protected Areas in Areas Beyond National Jurisdiction of the OSPAR Maritime Area', at p. 3; and D Owen, Interactions Between Management of a Water Column Marine Protected Area in the High Seas of the OSPAR Maritime Area and the Exercise of Sovereign Rights regarding Subjacent Outer Continental Shelf (Report for wwF Germany, 2010).

18 DJ Bederman, 'The sea' in B Fassbender and A Peters (eds), The Oxford Handbook of the History of International Law (Oxford University Press, Oxford, 2012) 359-380, at p. 363. See also A Kirchner, 'The Law of the Sea, History of' (September 2007) Max Planck Encyclopedia of Public International Law, at para 6. 
seas were made by various European entities during the Middle Ages, including the city-States Genoa in relation to the Ligurian Sea, and Venice in relation to the Adriatic Sea. ${ }^{19}$

Radically different were the Papal Bull Inter Caetera of 14 May 1493 and the subsequent bilateral 1494 Treaty of Tordesillas between Portugal and Spain. By means of the latter, the two States claimed sovereignty over all territories discovered or to be discovered east and west of a straight line from the geographical North Pole to the geographical South Pole. In addition, they claimed an exclusive right of navigation for Portugal in the Indian Ocean and the South Atlantic Ocean, and for Spain in the West Atlantic Ocean, the Gulf of Mexico, and the Pacific Ocean. ${ }^{20}$ These unilateral assertions blessed by the Catholic Church were challenged by Grotius in his 1609 manuscript Mare Liberum, ${ }^{21}$ which argues that the seas are incapable of occupation and governed by a regime of freedom. This eventually evolved into the present regime of the freedom of the high seas, the associated status of the high seas as res communis and the associated primacy of flag State jurisdiction on the high seas. ${ }^{22}$ Flag State jurisdiction is based on the nationality principle, which in its turn is based on each State's sovereignty-derived right to grant its nationality to ships. ${ }^{23}$

Mare Liberum subsequently triggered the famous 'battle of the books', in which authors such as William Wellwood and John Selden argued in favour of State authority over waters close to shore, ${ }^{24}$ thereby de facto advocating the notion of adjacency. This argument was in the end also accepted by Grotius. ${ }^{25}$ For a considerable period of time, States disagreed on the legal status of these coastal waters but eventually settled on sovereignty, and named these waters the territorial sea. ${ }^{26}$ The fundamental importance of the notion of adjacency

19 Bederman (n 18), at p. 364.

$20 \quad$ Kirchner (n 18$)$, at para 8.

21 H Grotius, 'Mare liberum sive de iure quod Batavis competit ad Indicana commercia, dissertatio' ('The Freedom of the Seas or The Right Which Belongs to the Dutch to Take Part in the East Indian Trade' (16o9), translated by R Van Deman Magoffin (1916).

22 LOSC (n 3), Articles 87(1), 92(1).

23 Ibid., Article 91(1).

24 T Treves, 'Historical Development of the Law of the Sea' in Rothwell, Oude Elferink, Scott and Stephens (n 4$) 1-23$, at p. 4.

25 Ibid.

26 Convention on the Territorial Sea and the Contiguous Zone (Geneva, 29 April 1958, in force 10 September 1964) 526 UNTS 205, Article 1(1) [1958 TSCZC]. The International Law Commission (ILC) opted for the term territorial sea in its 1956 'Articles concerning the law of the sea' (see the 'Commentary to the articles concerning the law of the sea' (1956) II Yearbook of the International Law Commission 265. 
was also reflected in the principle 'the land dominates the sea', which was postulated by the International Court of Justice (ICJ) in 1951, when it famously ruled: 'It is the land which confers upon the coastal State a right to the waters off its coasts.'. 27

Once adjacency was generally accepted as a basis for authority at sea, coastal States started claiming new rights and new maritime zones further and further from shore at the expense of the high seas regime. This process of creeping coastal State jurisdiction can be regarded as having commenced towards the end of the nineteenth century with claims on at-sea enforcement powers relating to smuggling and hot pursuit, ${ }^{28}$ while it continued during the negotiations on the LOSC at the third United Nations Conference on the Law of the Sea (UNCLOS III) between 1973 and 1982. Although this process was essentially unilateral in nature, joint claims occurred as well (e.g., the trilateral 1952 Santiago Declaration by Chile, Ecuador and $\mathrm{Peru}^{29}$ ). As all claims were in violation of the then existing international law of the sea, claimants sought to justify their actions by articulating their underlying rationale(s) and interests. These articulations can be regarded as being aimed at satisfying the requirement of opinio iuris in the context of the formation of customary international law. Well-known in this regard is the 1945 Truman Continental Shelf Proclamation, ${ }^{30}$ which led many other coastal States to make similar claims within a very short time-frame, possibly leading to what is sometimes called 'instant customary international law'.31 This practice was eventually codified in the 1958 Continental Shelf Convention, ${ }^{32}$ which also uses the notion of adjacency in the definition of the continental shelf in Article 1.

27 Fisheries case (United Kingdom v. Norway), Merits, Judgment of 18 December 1951, ICJ Reports 1951, 116 at p. 133. In the Jan Mayen case (Maritime Delimitation in the Area between Greenland and Jan Mayen (Denmark v. Norway), Merits, Judgment of 14 June 1993, ICJ Reports 1993, 38) the ICJ observed: 'the attribution of maritime areas to the territory of a State ... is a legal process based solely on the possession by the territory concerned of a coastline' (at p. 74, para 80).

28 Treves (n 24), at pp. 6-7.

29 Declaration on the Maritime Zone (Santiago, 18 August 1952, in force same day) 1006 UNTS 323 .

30 Proclamation 2667, 'Policy of the United States With Respect to the Natural Resources of the Subsoil and Sea Bed of the Continental Shelf', 28 September 1945; available at www .presidency.ucsb.edu/node/231308.

31 See B Cheng, 'United Nations resolutions on outer space: Instant International customary law?' (1965) 5 Indian Journal of International Law 23-48.

32 Convention on the Continental Shelf (Geneva, 29 April 1958, in force 10 June 1964) 499 UNTS 311 [1958 CSC]. 


\section{From UNCLOS I to UNCLOS III}

After some initial but unsuccessful attempts at codifying the customary international law of the sea prior to World War II, the first United Nations Conference on the Law of the Sea (UNCLOS I) - held in 1958 - succeeded in adopting four conventions ${ }^{33}$ and a protocol on dispute settlement. This codified three coastal State maritime zones - namely, the territorial sea, the contiguous zone and the continental shelf; albeit with precise outer limits only for the contiguous zone, ${ }^{34}$ and three exceptions to the primacy of flag State jurisdiction on the high seas - namely, in relation to piracy, the slave trade and hot pursuit. ${ }^{35}$ The last of these is exclusively available for coastal States.

The inability of UNCLOS I to agree on a maximum breadth of the territorial sea and the nature and extent of special rights for coastal States over fish stocks adjacent to their territorial seas ${ }^{36}$ led to the convening of the second United Nations Conference on the Law of the Sea (UNCLOS II) in 1960. UNCLOS II did not have an agreed outcome even though a compromise proposal for a six $\mathrm{M}$ territorial sea and a six M fishing zone failed by just one vote. Twelve M EFZs nevertheless gained increasingly further ground in State practice in the 196 os. $^{37}$

The 1967 Torrey Canyon disaster led to the adoption of various new instruments within the International Maritime Organization (IMO), including the 1969 Intervention Convention, ${ }^{38}$ which recognised the right of coastal States to take necessary intervention measures on the high seas in response to maritime casualties involving foreign ships.

UNCLOS III formally commenced in 1973 among widespread but diverging State practice on claims to breadths of territorial seas and EFZs. An early proposal at UNCLOS III for a $200 \mathrm{M} \mathrm{EEZ} \mathrm{soon} \mathrm{made} \mathrm{its} \mathrm{way} \mathrm{into} \mathrm{State} \mathrm{practice}$ and at least its general aspects had already become part of customary international law before the end of UNCLOS III. Nothing in general international

33 In addition to the $1958 \mathrm{TSCZC}(\mathrm{n} 26)$ and the $1958 \mathrm{csc}\left(\mathrm{n}_{32}\right)$, there are the Convention on Fishing and Conservation of the Living Resources of the High Seas (Geneva, 29 April 1958, in force 20 March 1966) 559 UNTS 285 [1958 HSFC], and the Convention on the High Seas (Geneva, 29 April 1958, in force 30 September 1962) 450 UNTS 11 [1958 HSC].

34 See 1958 tsczc (n 26), Articles 6 and 24(2); 1958 csc (n 32), Article 1.

$35 \quad 1958$ HSC (n 33), Articles 19-23.

36 Coastal States eventually found the rights laid down in Articles 6-7 and 13 of the 1958 HSFC (n 33) and Article 2(4) of the $195^{8} \mathrm{CSC}\left(\mathrm{n}_{32}\right)$ to be inadequate. See also the 1956 ILC Commentary (n 26), at pp. 286-293.

37 DR Rothwell and T Stephens, The International Law of the Sea (Hart Publishing, Oxford/ Portland, 2010), at pp. 9-10.

38 International Convention relating to Intervention on the High Seas in Cases of Oil Pollution Casualties (Brussels, 29 November 1969, in force 6 May 1975) 970 UNTS 211. 
law suggests that the new customary right to an EEZ affected the pre-existing right to an EFZ. In line with the principle in maiore stat minus (who can do more can also do less), some coastal States continue to claim only EFzs today. In addition to the EEZ, the LOSC recognised that certain coastal States qualify as archipelagic States and are entitled to designate waters enclosed by archipelagic baselines drawn in accordance with the LOSC as archipelagic waters. These waters then become part of those archipelagic States' territories and subject to their sovereignty. ${ }^{39}$

The LOSC broadened the right of hot pursuit to account for the new coastal State maritime zones, ${ }^{40}$ and also lowered the requirements for the exercise of the right of intervention in comparison with the requirements of the Intervention Convention. ${ }^{41}$ None of the additional exceptions to the primacy of flag State jurisdiction on the high seas - namely, unauthorised broadcasting and ships without nationality - are exclusively available to coastal States. ${ }^{42}$ The rights relating to unauthorised broadcasting are nevertheless tailored in particular to broadcasting from areas adjacent to the outer limit of the territorial sea of coastal States. ${ }^{43}$

\section{Post-UNCLOS III}

UNCLOS III was successful in bringing an end to unilateral coastal State claims to new maritime zones; the principal exception being Chile's Mar Presencial proclaimed in $1991 .{ }^{44}$ Several other States (e.g., Canada, Russia and the United States) also considered unilateral assertions of coastal State jurisdiction in ABNJ towards the end of the 198 os and in the mid-20oos, but eventually opted for multilateral solutions. ${ }^{45}$

$39 \operatorname{LOSC}\left(\mathrm{n}_{3}\right)$, Articles 2, 46-47, 49.

40 Ibid., Article 111, paras 1-2.

41 Ibid., Article 221; see also I Parlov, Coastal State Jurisdiction over Ships in Peril and Shipwrecks (PhD thesis, UiT The Arctic University of Norway, March 2020).

$42 \quad$ LOSC (n 3), Articles 109-110.

43 Ibid., Article 58(2) and paras $3(\mathrm{~d})$ and (e) of Article 109.

44 EJ Molenaar, 'New maritime zones and the law of the sea' in H Ringbom (ed), Jurisdiction over Ships - Post-UNCLOS Developments in the Law of the Sea (Brill/Nijhoff. Leiden, 2015) 249-277.

45 See Kwiatkowska (n 2), at pp. 169-170; DA Balton, 'Strengthening the law of the sea: The new agreement on straddling fish stocks and highly migratory fish stocks' (1996) 27 Ocean Development and International Law 125-151, at p. 131; EJ Molenaar, 'Participation in the Central Arctic Ocean Fisheries Agreement' in A Shibata, L Zou, N Sellheim and M Scopelliti (eds), Emerging Legal Orders in the Arctic: The Role of Non-Arctic Actors (Routledge, London/New York, 2019) 132-170, at pp. 142-143. 
Creeping coastal State jurisdiction nevertheless continued in the post-LOSC era, both unilaterally ${ }^{46}$ and multilaterally. Multilateral creeping coastal State jurisdiction has occurred at both the regional and the global level. Occurrences at the regional level seem to be confined to the domain of international fisheries law. These have manifested themselves in particular though the rules and practices on participation, allocation of fishing opportunities and combating illegal, unreported and unregulated (IUU) fishing of several regional fisheries management organisations (RFMOs), ${ }^{47}$ whose implementation has ensured that membership is limited to, or dominated by, coastal States. A pertinent example in this regard is the North-East Atlantic Fisheries Commission (NEAFC). ${ }^{48}$

At the negotiations on the 2018 CAOF Agreement ${ }^{49}$ - which took place during 2015-2017 and related exclusively to the high seas portion of the central Arctic Ocean - several delegations asserted special roles, interests and rights for adjacent coastal States. These assertions proved unsuccessful, however, as other delegations were concerned about their potential precedent-setting effects; not only for the domain of international fisheries law, but also for the BBNJ negotiations. ${ }^{50}$

Examples of multilateral creeping coastal State jurisdiction at the global level in the post-UNCLOS III era include the coastal State jurisdiction beyond the outer limit of the territorial sea relating to (a) mandatory ships' routeing measures and ship reporting systems created by the 1974 SolAs Convention ${ }^{51}$ adopted under the auspices of IMO, which coastal States can impose on foreign vessels after obtaining IMO approval, ${ }^{52}$ (b) underwater cultural heritage created by the Underwater Cultural Heritage Convention adopted under the auspices of UNESCO and (c) the removal of wrecks created by the 2007 Wreck

$46 \quad$ See $\mathrm{n} 4-5$ and accompanying text.

47 This acronym comprises regional fisheries management arrangements (RFMAs), unless indicated otherwise.

48 See EJ Molenaar, 'Cooperation through regional fisheries management organizations' in A Østhagen and A Raspotnik (eds), Marine Resources, Climate Change, and International Management Regimes (Bloomsbury, London, forthcoming) at section 3.2.

49 Agreement to Prevent Unregulated High Seas Fisheries in the Central Arctic Ocean (Ilulissat, 3 October 2018, not in force) OJ 2019, L 73/3.

50 Molenaar 2019 (n 45), at pp. 142-144.

51 International Convention for the Safety of Life at Sea (London, 1 November 1974, in force 25 May 1980) 1184 UNTS 277; with protocols and regularly amended. See Regulations V-1O and V11.

$5^{2}$ Despite an explicit basis for this in the LOsC; see EJ Molenaar, Coastal State Jurisdiction over Vessel-Source Pollution (Kluwer Law International, The Hague, 1998), at p. 527. 
Removal Convention ${ }^{53}$ adopted under the auspices of I $\mathrm{mo}$. All these examples amount to the thickening of coastal State jurisdiction and not its creeping into ABNJ.

Arguably, the 1995 Fish Stocks Agreement ${ }^{54}$ cannot be regarded as an advance of creeping coastal State jurisdiction into ABNJ either; at any rate not a significant advance. The Fish Stocks Agreement seeks to implement the general provisions of the LOSC on straddling and highly migratory fish stocks by means of a modernised and more elaborate and operationalised regulatory framework. The inclusion of an operationalised precautionary approach and a de facto ecosystem approach, ${ }^{55}$ the clarification that RFMOs are the preeminent vehicles for the conservation and management of straddling and highly migratory fish stocks, ${ }^{56}$ and the intricate provisions on non-flag State high seas enforcement (Articles 21-22) bear witness to that objective.

During the negotiations on the Fish Stocks Agreement, coastal States did in fact make proposals that amounted to creeping coastal State jurisdiction into ABNJ - namely, in the context of the notion of compatibility as eventually laid down in Article 7 - and also preferred the geographical scope of the Agreement to be strictly confined to ABNJ. For their part, high seas fishing States preferred a non-legally binding outcome of the negotiations. The key elements of the package deal that secured a successful conclusion of the negotiations were a legally binding outcome and the partial applicability of the Agreement to AWNJ as reflected in paragraphs 1 and 2 of Article $3 .{ }^{57}$

Also critically important for the adoption of the Fish Stocks Agreement by consensus were the final texts on compatibility and non-flag State high seas enforcement. It is submitted that the largely even-handed and reciprocal way in which Article 7 operationalises compatibility avoids significantly favouring either coastal States or high seas fishing States. The negotiations on non-flag State high seas enforcement were especially sensitive in light of Canada's unilateral decision in 1994 to assert enforcement jurisdiction over foreign vessels

53 Nairobi International Convention on the Removal of Wrecks (Nairobi, 18 May 2007, in force 14 April 2015) IMo Doc. LEG/CONF.16/19 (23 May 2007). See Articles 8-10. See also Parlov (n 41).

54 Agreement for the Implementation of the Provisions of the United Nations Convention on the Law of the Sea of 10 December 1982 relating to the Conservation and Management of Straddling Fish Stocks and Highly Migratory Fish Stocks (New York, 4 August 1995, in force 11 December 2001) 2167 UNTS 3 [Fish Stocks Agreement]. Ibid., Articles 5, 6 and Annex II.

56 Ibid., Articles 8(3), 17(1).

57 Balton (n 45), at pp. 134-135, 137; see also AC de Fontaubert, 'The politics of negotiation at the United Nations Conference on Straddling Fish Stocks and Highly Migratory Fish Stocks' (1995) 29 Ocean \& Coastal Management 79-91, at pp. 81-82. 
targeting straddling fish stocks on the high seas adjacent to its Atlantic E EZ, ${ }^{58}$ and its actual exercise of that jurisdiction with respect to the Spanish fishing vessel Estai on 9 March 1995, just prior to the penultimate session of the negotiations. In light of these events, it is not surprising that the carefully defined exception to the primacy of flag State jurisdiction on the high seas laid down in Articles 21 and 22 makes no reference to coastal States. Just like any other party to the Agreement, adjacent coastal States are of course also entitled to exercise these high seas enforcement powers, and there could be circumstances that would make them more likely to do so than other parties. ${ }^{59} \mathrm{Up}$ until now, however, Articles 21 and 22 have never been formally invoked and non-flag State high seas enforcement has been conducted exclusively on an inter se basis between members and cooperating non-contracting parties of RFMOs. ${ }^{60}$

It is submitted that only Articles 8(3) and 2o(6) of the Fish Stocks Agreement give coastal States new - albeit limited - rights in AB NJ. Paragraph 3 of Article 8 acknowledges the right of States with a real interest to become members of RFMOS. In light of the wording of paragraph 3 as a whole, it is clear that at any rate coastal States have a real interest. This is obvious for 'tuna' RFMOs - whose geographical mandates cover both $\mathrm{ABNJ}$ and $\mathrm{AWNJ}$ - but it is also logical for RFMOs with competence over straddling fish stocks, even though their geographical mandates commonly cover only ABNJ. Article $20(6)$ gives coastal States a right to request flag States to investigate instances of unauthorised fishing by their vessels in coastal State maritime zones in a scenario when such vessels are on the high seas and coastal States are unable to exercise the right of hot pursuit.

Even though the Fish Stocks Agreement was adopted by consensus, as of mid-December 2020 its status of participation was considerably less universal compared to that of the LOSC: 91 vs 168 parties. ${ }^{61}$ The Agreement's provisions on compatibility and non-flag State high seas enforcement were - and presumably still are - among the reasons for States not to become parties to the

58 See section 5.2 of Canada's Coastal Fisheries Protection Act (R.s.C., 1985, c. C-33) in conjunction with S. 21(2)(b)(ii) and Table III of its Coastal Fisheries Regulations (C.R.C., c. 413).

59 Some similarities exist in this regard with unauthorised broadcasting on the high seas as discussed in (n 43) and accompanying text.

6o See RG Rayfuse, Non-Flag State Enforcement in High Seas Fisheries (Martinus Nijhoff Publishers, Leiden, 2004). This author is not aware of any indications that suggest that the findings and conclusions in by Rayfuse in 2004 need to be significantly adjusted in light of subsequent events and practices.

61 Information available at https://www.un.org/Depts/los. 
Agreement. ${ }^{62}$ Some States took - and presumably still take - the view that these provisions disregard the UNGA's mandate and instructions to ensure consistency with the LOSC, ${ }^{63}$ despite these having been laid down in Article 4 of the Agreement. ${ }^{64}$ The views and concerns of these States are directly relevant to the BBNJ negotiations as Article 4(1) of the First Draft is identical to Article 4 of the Fish Stocks Agreement. ${ }^{65}$ The provisions read:

Nothing in this Agreement shall prejudice the rights, jurisdiction and duties of States under the Convention. This Agreement shall be interpreted and applied in the context of and in a manner consistent with the Convention.

The dilemma here revolves around diverging views on what is necessary to achieve the objective of a LOSC implementing agreement and if this is consistent with key features of the LOSC, such as its object, purpose and general or basic principles. ${ }^{66}$ However, not unlike beauty, whether something is consistent and merely a matter of implementation rather than modification, is in the eye of the beholder. This is of course different for the 1994 Part XI Deep-Sea Mining Agreement, ${ }^{67}$ which is only a LOsC implementing agreement in name as its provisions indisputably make it a modification agreement in substance. ${ }^{68}$ In case the LOSC does not address particular problems or issues at all, or only superficially or inadequately by means of a limited number of general provisions, it is almost inevitable that subsequent dedicated negotiations lead to an expansion in the number of provisions and their level of detail. Such negotiations will also be influenced by developments that have taken place since the adoption of the LOsC in 1982 relating to, inter alia, knowledge, technology and the composition, needs and interests of the international community.

62 EJ Molenaar, 'Non-participation in the Fish Stocks Agreement: Status and reasons' (2011) 26 International Journal of Marine and Coastal Law 195-234.

63 UNGA Res 47/192 (22 December 1992) United Nations conference on straddling fish stocks and highly migratory fish stocks, UN Doc A/RES/47/192.

64 See also Fish Stocks Agreement (n 54), Article 2.

65 It is also virtually identical to Article 3 of the Underwater Cultural Heritage Convention (n 7$)$.

66 See LOSC (n 3), Articles 237, 311.

67 Agreement relating to the Implementation of Part XI of the United Nations Convention on the Law of the Sea of 10 December 1982 (New York, 28 July 1994, in force 28 July 1996) 1836 UNTS 42.

68 See Article 2(1), which reads: "The provisions of this Agreement and Part XI shall be interpreted and applied together as a single instrument. In the event of any inconsistency between this Agreement and Part XI, the provisions of this Agreement shall prevail'. 
This may mean that adjustments in terms of modernisation and equity are called for. ${ }^{69}$

Finally, in addition to the phenomena of unilateral and multilateral creeping coastal State jurisdiction, attention should be drawn to the significant impact that coastal States have had, and continue to have, on the progressive development of the international law of the sea on account of their attempts and successes in confining such development to ABNJ and thereby avoiding internationally agreed restraints on their sovereignty, sovereign rights and jurisdiction in AWNJ. ${ }^{70}$ This has led, and can lead, to situations where regulation is more stringent in ABNJ than in AWNJ and coastal States have competitive advantages. A good example are the roles and outcomes of the UNGA and the Food and Agriculture Organization of the United Nations (FAO) on the regulation of bottom fishing - which targets species close to the seabed by using gear that can cause significant adverse impacts on benthic vulnerable marine ecosystems (VMEs) - and fishing for deep-sea species. These roles and outcomes were confined to the high seas ${ }^{71}$ even though such fishing can be just as harmful if carried out in AWNJ. Other examples are the coastal States' preference to strictly confine the geographical scope of the Fish Stocks Agreement to $\mathrm{ABNJ}^{72}$ and the strategic decisions by the central Arctic Ocean coastal States to ensure that the CAOF Agreement would be confined to the high seas, ${ }^{73}$ without also developing a multilateral coastal State fisheries management mechanism for adjacent AWNJ similar to, or with similar effectiveness as, the CAOF Agreement. ${ }^{74}$ The last, but not the least, example are the вBNJ negotiations,

69 For similar views with respect to the Fish Stocks Agreement, see M Hayashi, 'The 1995 Agreement on Straddling Fish Stocks and Highly Migratory Fish Stocks: Significance for the Law of the Sea Convention' (1995) 29 Ocean \& Coastal Management 51-69 in general and p. 59 in particular.

See $\mathrm{T}$ Treves 'Principles and objectives of the legal regime governing areas beyond national jurisdiction' in AG Oude Elferink and EJ Molenaar (eds), The International Legal Regime of Areas Beyond National Jurisdiction: Current and Future Developments (Martinus Nijhoff Publishers, Leiden, 2010) 7-25, at pp. 8-12.

71 See Unga Res 61/105 (8 December 2006) Sustainable fisheries, Un Doc A/RES/61/105, paras $83-85$ (which are implicitly confined to the high seas as they relate to RFMOs with competence over 'residual' species, whose geographical scope is commonly limited to ABNJ) and 86, and the title of the International Guidelines for the Management of Deep-sea Fisheries in the High Seas (Rome, 29 August 2008; Appendix F to the Report of the Technical Consultation on International Guidelines for the Management of Deep-sea Fisheries in the High Seas, Rome, 4-8 February and 25-29 August 2008 (FAO Fisheries and Aquaculture Report No. 881) as well as paras 8 and 10.

72 See (n 57 ) and accompanying text.

73 See Molenaar 2019 (n 45), at pp. 133, 140.

74 Ibid., at pp. 140-141 on the relevance of Article 3(6) of the CAOF Agreement. 
which are - as a general rule subject to potential exceptions - geographically confined to ABNJ. ${ }^{75}$

\section{Adjacency, Superjacency, Subjacency and ABNJ in the LOSC and the Fish Stocks Agreement}

\section{Introduction}

The term adjacent is used in a considerable number of provisions of the LOSC. A part of these provisions is related to maritime delimitation. ${ }^{76}$ Of the remainder, ${ }^{77}$ only Article 63(2) concerns adjacency and ABNJ. This provision requires coastal States and high seas fishing States to cooperate on straddling fish stocks by agreeing on the necessary conservation and management measures for these stocks in the adjacent high seas area. Much of this provision's wording is reproduced in Article 7(1)(a) of the Fish Stocks Agreement.

The term superjacent is used in several LOSC provisions in relation to the waters above the (outer) continental shelf and the Area, and the airspace above those waters. Whereas one of these is merely a geographical clarification as to which waters are relevant, ${ }^{78}$ two others contain non-prejudice clauses to safeguard the legal status of the superjacent waters and air space. ${ }^{79}$ The LOSC does not use the term subjacent and the Fish Stocks Agreement uses neither superjacent nor subjacent.

The notions of adjacency, superjacency and subjacency have, in relation to $A B N J$, been incorporated in the LOSC and the Fish Stocks Agreement in connection with rights and mechanisms. Rights in ABNJ can be

a) granted explicitly to coastal States, namely the rights in Articles 111 (hot pursuit) and 221 (intervention) of the LOSC and Articles 8(3) and 20(6) of the Fish Stocks Agreement; ${ }^{80}$

b) granted implicitly to coastal States as they relate to their sovereign rights over their continental shelves (e.g., the exclusive rights to use the waters of the high seas for drilling on the continental shelf or targeting sedentary species, that are implied in Articles 77(4) and 81 of the LOSC); or

75 See the subsection 'Preamble and General Provisions'.

$76 \operatorname{LOSC}\left(\mathrm{n}_{3}\right)$, Articles 15, 74, 76(10), 83, 134(4), and Article 9 of Annex II.

77 Ibid., Articles 2(1), 47(6), 51(1), 53(1) and (4), 55, 63 .

78 Ibid., Article 56(1)(a).

79 Ibid., Articles 78(1), 135. See also Article 155(2).

$80 \quad$ On Articles 8(3) and 2o(6) see the subsection 'Post-UnClos III'. 
c) tailored to coastal States and their interests, namely the rights in Articles 109-110 of the LOSC on unauthorised broadcasting, and - to a lesser extent - Articles 21-22 of the Fish Stocks Agreement on non-flag State high seas enforcement.

The mechanisms address the transboundary impacts of activities, undertaken in ABNJ pursuant to the rights and jurisdiction of all States, on the sovereignty, sovereign rights, other rights and jurisdiction of coastal States in AWNJ, and/or vice versa. The purpose of these mechanisms is to protect or safeguard the various interests associated with the rights in $\mathrm{ABNJ}$ and $\mathrm{AWNJ}$ through substantive and procedural constraints, whether even-handed and reciprocal or not.

The LOsC does not have a single overarching provision and mechanism to address transboundary interactions between ABNJ and AWNJ. There are nevertheless four specific scenarios for which the LOSC and the Fish Stocks Agreement have such mechanisms. Three of these can be categorised as issueoriented - namely, transboundary stocks and species, deep seabed mining, and protection and preservation of the marine environment - and one as zone-oriented, namely, high seas waters superjacent to the continental shelf. These scenarios are discussed in the next subsections.

In addition, the LOSC has single overarching provisions and mechanisms to accommodate the interaction between the rights of coastal States and other States within the $\mathrm{EEZ}^{81}$ and between the rights of all States on the high seas. ${ }^{82}$ The mechanism used by these provisions is an obligation of due regard. Some scholars argue that the principle of due regard is, inter alia, due to the jurisprudence of international courts and tribunals, applicable in all scenarios as it is a general organising principle in the law of the sea ${ }^{83}$ that is arguably part of customary international law. ${ }^{84}$ Finally, the use of different terminology may not necessarily always be significant. The tribunal in the Chagos Arbitration considered the obligation to refrain from unjustifiable interference laid down

\footnotetext{
$81 \quad$ Ibid., Articles 56(2), 58(3). See also Article 59.

82 Ibid., Article $87(2)$.

83 BH Oxman, 'The principle of due regard', in International Tribunal for the Law of the Sea, The Contribution of the International Tribunal for the Law of the Sea to the Rule of Law, 1996-2016 (Brill/Nijhoff, Leiden, 2018) 108-116.

84 T Treves, "Due regard" obligations under the 1982 Un Convention on the Law of the Sea: The laying of cables and activities in the Area' (2019) 34 International Journal of Marine and Coastal Law 167-194, at p. 182. See also AG Oude Elferink, 'Coastal States and MPAs in ABNJ: Ensuring consistency with the LOSC' (2018) 33 International Journal of Marine and Coastal Law 437-466, at pp. 447-448.
} 
in Article 194(4) of the LOSC to be 'functionally equivalent' to the obligation of due regard set out in Article $56(2)$ of the Losc. ${ }^{85}$

\section{Transboundary Stocks and Species}

This scenario comprises straddling, highly migratory and anadromous fish stocks, catadromous species and marine mammals. It is primarily horizontal (adjacent) in nature, as the vertical (superjacent/subjacent) interactions on fishing are primarily captured by the high seas-continental shelf scenario discussed further below. As regards straddling and highly migratory fish stocks, the mechanism consists of operationalised obligations to cooperate in order to achieve compatibility. 86 This requires, among other things, that measures applicable to the 'high seas component' of such stocks do not undermine the effectiveness of measures applicable to the 'coastal component'. ${ }^{87}$ As regards anadromous fish stocks, the mechanism is shaped in particular by operationalising the recognition that States of origin have the primary interest in, and responsibility for, such stocks, inter alia, by means of a near-prohibition of high seas fishing. ${ }^{88}$ As regards catadromous species, the mechanism is shaped in particular by recognising the responsibility of coastal States and prohibiting high seas fishing. ${ }^{89}$ The mechanism on marine mammals consists of a nonoperationalised obligation to cooperate. ${ }^{90}$

In relation to straddling, highly migratory and anadromous fish stocks, the LOSC specifies that cooperation can occur directly or through regional (intergovernmental) organisations. For marine mammals, however, the LOSC stipulates that cooperation must in particular occur through organisations. A similar primacy of cooperation through organisations is laid down in the Fish Stocks Agreement, which recognises that RFMOs are the preeminent vehicles for the conservation and management of straddling and highly migratory fish stocks. ${ }^{91}$ Such preeminent organisations can be said to have become an integral part of the relevant mechanism for addressing transboundary interactions between ABNJ and AWNJ laid down in the LOSC and the Fish Stocks Agreement. Or, viewed differently, their indispensable role in such mechanisms is one of the primary functions of such organisations. Finally, as RFMOs with competence

\footnotetext{
85 Chagos Marine Protected Area Arbitration (Mauritius v. United Kingdom), Award of 18 March 2015, PCA Case No. 2011-03, at para 540.

$86 \operatorname{LOSC}\left(\mathrm{n}_{3}\right)$, Articles 63(2), 64, 116; Fish Stocks Agreement (n 54), Articles 7-8.

87 Fish Stocks Agreement (n 54), Article 7(2)(a).

$88 \operatorname{LosC}\left(\mathrm{n}_{3}\right)$, Article 66.

89 Ibid., Article 67.

$90 \quad$ Ibid., Article 65.

91 See ( $\mathrm{n}_{56}$ ) and accompanying text.
} 
over straddling and highly migratory fish stocks are now an integral part of the abovementioned mechanism, the right accorded to coastal States pursuant to Article 8(3) of the Fish Stocks Agreement to become members of such RFMOs is not just a logical corollary, but an essential prerequisite for the proper functioning of the mechanism.

\section{Deep Seabed Mining}

This scenario has both a horizontal (adjacent) and a vertical (superjacent/subjacent) component. The vertical component is governed by Articles $87(2)$ and 147(1) and (3). The mechanism in Article 87(2) is an obligation of due regard and is one-sided as it only constrains the exercise of high seas rights. Paragraphs 1 and 3 of Article 147 address this shortcoming by a reciprocal and symmetrical mechanism based on obligations of reasonable regard. This mechanism is not exclusively vertical in nature, however, as it applies to activities in the Area visà-vis activities in the "marine environment" and vice versa. Whereas the term 'marine environment' is not defined in the LOSC, and therefore creates ambiguity as to whether the airspace above marine waters is included or not, there are evidently no such doubts on marine waters, the seabed and its subsoil. This implies that this mechanism also has a horizontal component (Area $\Leftrightarrow$ seabed in AWNJ, including the continental shelf) as well as a 'diagonal' component (Area $\Leftrightarrow$ marine waters in AWNJ, including the EEZ).

Conversely, the mechanism relating to transboundary deposits of minerals of the Area and the continental shelf governed by Article 142(1) and (2) of the LOSC is exclusively horizontal in nature. The mechanism is based on an operationalisation of an obligation of due regard and is one-sided as it constrains only activities in the Area. This shortcoming is to some extent addressed by the prohibition on alienation in Article 137(2) as well as the non-operationalised obligation of reasonable regard in relation to activities in Article 147(3), discussed above.

\section{Protection and Preservation of the Marine Environment}

Part XII of the LOSC contains provisions that are relevant to the issues under examination in different ways. The general obligation to protect and preserve the marine environment in Article 192 also applies to transboundary environmental damage between ABNJ and AWNJ. Paragraph 2 of Article 194 focuses specifically on pollution damage caused by one State to another, using wording broad enough to also cover transboundary pollution between $\mathrm{ABNJ}$ and AWNJ. Its mechanism is based on an obligation to take 'all measures necessary'. Paragraph 4 of Article 194 applies to transboundary as well as 
non-transboundary scenarios and uses a mechanism based on a prohibition of unjustifiable interference. In contrast with all other provisions discussed above, however, this mechanism does not constrain a State's exercise of a right but its compliance with an obligation, namely 'taking measures to prevent, reduce or control pollution of the marine environment'. ${ }^{92}$ All these mechanisms apply in horizontal as well as vertical scenarios. Finally, even though the obligation to conduct an environmental impact assessment (EIA) laid down in Article 206 does not apply specifically to transboundary scenarios, conducting an EIA can certainly function as a process to operationalise the abovementioned mechanisms to address transboundary interactions between ABNJ and AWNJ.

\section{High Seas-Continental Shelf}

This scenario is exclusively vertical but not issue-specific as it covers the full spectrum of interactions between the coastal State's sovereign rights, jurisdiction and other rights over its continental shelf, and the rights of all States in the superjacent waters and airspace..$^{93}$ Of the multiple mechanisms applicable to this scenario, ${ }^{94}$ the principal one is included in Article $78(2)$. It is based on an implicit obligation for coastal States to ensure that the exercise of their rights does 'not infringe or result in any unjustifiable interference with' the rights of other States. The one-sided nature of this mechanism is softened somewhat by the mechanism in Article 116(b), which makes the right to fish on the high seas 'subject to ... the rights and duties as well as the interests of coastal States provided for, inter alia, in' Articles 63(2) and 64-67. The words 'inter alia' ensure that the rights and interests of coastal States vis-à-vis their sedentary species are also incorporated. Moreover, the need to take account of environmental factors pursuant to Article 119(a) also requires high seas fishing States to address adverse impacts of their fishing practices on continental shelves. ${ }^{95}$

The mechanism relating to artificial islands, installations and structures laid down in Article 6o in conjunction with the mutatis mutandis provision in

92 Article 194(4) in full reads: 'In taking measures to prevent, reduce or control pollution of the marine environment, States shall refrain from unjustifiable interference with activities carried out by other States in the exercise of their rights and in pursuance of their duties in conformity with this Convention'.

93 See more generally J Mossop, The Continental Shelf Beyond 200 Nautical Miles: Rights and Responsibilities (Oxford University Press, Oxford, 2016), Chapter 7.

94 Article 79 is not discussed as the laying and maintenance of cables and pipelines on the continental shelf are categorised as activities relating to the continental shelf, despite the fact that they necessarily also involve activities relating to the water column.

95 See EJ Molenaar, 'Addressing regulatory gaps in high seas fisheries' (2005) 20 International Journal of Marine and Coastal Law 533-570, at p. 559. 
Article 80 can be regarded as an operationalisation of the one-sided mechanism in Article 78(2). Paragraph 7 of Article 6o imposes an implicit obligation on coastal States not to establish artificial islands, installations and structures 'where interference may be caused to the use of recognised sea lanes essential to international navigation. Where construction is allowed, paragraph 3 imposes an implicit obligation on coastal States to give due notice of construction and use, as well as several implicit obligations relating to abandoned and disused installations and structures, including by means of due regard.

The need for further operationalisation of the mechanisms in Articles 78(2) and 116 (b) has arisen in particular in relation to high seas bottom fisheries that can cause significant adverse impacts on vMEs located on continental shelves. ${ }^{96}$ As a preliminary matter, this required agreement on common interpretations of various ambiguities on the scope and extent of the coastal State's sovereign rights laid down in Article 77. These ambiguities include whether (a) sovereign rights also include the necessary jurisdiction; (b) such jurisdiction can also be used for conservation; and (c) sedentary species can be interpreted broadly to also include benthic vMEs. ${ }^{97}$ Affirmative interpretations on these ambiguities were eventually laid down in the 2008 International Guidelines for the Management of Deep-sea Fisheries in the High Seas ${ }^{98}$ and the annual UNGA sustainable fisheries resolutions from 2008 onwards. ${ }^{99}$

So far, however, no attempts seem to have been made at the global level to operationalise the mechanisms in Articles 78(2) and 116(b) in relation to high seas bottom fisheries above continental shelves. The situation at the regional level is different. The only attempt to explicitly operationalise Article $78(2)$ - but not also Article 116(b) - seems to have occurred in NEAFC, following

96 High seas fishing can also interfere with fishing for sedentary species on outer continental shelves or have predator-prey impacts on such sedentary species.

See Molenaar 2005 (n 95), at p. $55^{8}$.

98 See $\left(\mathrm{n}_{71}\right)$ at para 25.

99 Whereas UNGA Res 63/112, 5 December 2008, uses in para 104 similar language to para 25 of the 2008 International Guidelines, UNGA Res 64/72, 4 December 2009, para 115 expands this, including by a reference to Article 77 . Subsequent resolutions have kept this language without change. UNGA Res 66/68, 6 December 2011, at para 124 added thereto the following: 'Notes in this regard the adoption by coastal States of conservation measures regarding their continental shelf to address the impacts of bottom fishing on vulnerable marine ecosystems, as well as their efforts to ensure compliance with those measures'. No substantive changes were made to both paragraphs since then. See UNGA Res. 74/18, 10 December 2019, paras 196-197. See also note 101 infra, and the Norwegian position reflected in the North-East Atlantic Fisheries Commission (NEAFC), Working Group on Vulnerable Marine Ecosystems (VME), 6-7 March 2018 Report (WG VME(o2)-Report-(March 2018)), at p. 1 [NEAFC WG VME 2018]. 
the 2017 proposal by Norway and Russia to amend NEAFC Recommendation 19:2014 'on the Protection of Vulnerable Marine Ecosystems in the NEAFC Regulatory Area' in order to bring it 'fully into line with [the LOSC], in particular the rights and obligations of coastal States with regard to the continental shelf' ${ }^{\prime 00}$ Whereas Recommendation 19:2014 refers to coastal States and their continental shelves in the non-prejudice clause included in Article 1(3), ${ }^{101}$ coastal State members of NEAFC are not given a role in closing or opening an area to bottom fishing or otherwise regulating bottom fishing, for instance through gear specifications. Some States may take the view that such a role for coastal States amounts to (multilateral) creeping coastal State jurisdiction within ABNJ. ${ }^{102}$ The joint proposal by Norway and Russia also sought to address the absence of any reference in Recommendation 19:2014 to a coastal State's obligations or responsibility to protect VMEs. ${ }^{103}$ Conversely, the proposal does not seem to have also included the mechanism in Article 116(b) of the LOSC or any other way to take account of the obligations of high seas fishing States visà-vis coastal States in this context.

The NEAFC Working Group on VMEs that was established pursuant to the proposal by Norway and Russia met five times during 2018-2019 but was unable to find consensus on amendments to Recommendation 19:2014. ${ }^{104}$ This was among other things due to the concerns of one NEAFC Member in particular - but perhaps also others - for precedent-setting effects for other RFMOs and the ввNJ negotiations. ${ }^{105}$ There may also have been speculations that setting such precedents was part of the rationale behind the joint proposal by Norway and Russia. The final version of the amendment gives, on the one hand, a coastal State the right to withhold consent - a de facto veto therefore - on area

100 The citation is from NEAFC WG VME 2018, ibid., at p. 1. The initial explanation by Norway as reported in the Report of the 36th (2017) NEAFC Annual Meeting, at p. 7 is more ambiguous.

101 Note that Article 1(3) of NEAFC Recommendation 19:2014 also categorises VMEs as sedentary species.

102 See in this regard NEAFC WG VME 2018 (n 99), at p. 2: 'Several parties noted their view that coastal States did not have the right to manage high seas fisheries. High seas fisheries management was a task for regional fisheries management organisations and arrangements, which had to take full account of the rights of coastal States'.

103 Article 1(2) of the final version of the amendment - included in an unnumbered working paper on file with author - contains a recognition of the coastal State's responsibility.

104 Report of the 38th (2019) Annual NEAFC Meeting, para 18.1.

105 Based on information provided by participants in the last meeting of the NEAFC Working Group on vMEs to the author during conversations on 16 April and 6 and 14 May 2020. See also the reference to 'other wider negotiations' in para 18.2 of the Report of the 38 th (2019) Annual NEAFC Meeting. 
closures and redefinitions relating to its outer continental shelf. On the other hand, any other NEAFC Member is given the right to establish an ad hoc expert panel to assess a coastal State's withholding of consent in light of, inter alia, the implicit obligation in Article 78(2) of the Losc. A possible outcome of the panel's assessment can be that the coastal State's withholding of consent is disregarded. ${ }^{106}$ Although Norway had indicated that it would withdraw from Recommendation 19:2014 if the Working Group could not agree on satisfactory amendments, ${ }^{107}$ this had not occurred at the time of writing.

The relationship between the regimes of the high seas and outer continental shelves has also come up within the framework of the 2006 SIOFA, ${ }^{108}$ which is a regional fisheries management arrangement (RFMA) rather than a RFMO. Mauritius and Seychelles are both parties to SIOFA and have established their outer continental shelves as a joint management area (JMA) pursuant to a 2012 bilateral treaty. ${ }^{109}$ Article $12(\mathrm{~b})$ of that treaty stipulates that the obligation to apply the precautionary principle 'shall include measures concerning fishing activity in the waters superjacent to the seabed in the JMA where such activity is having a direct impact upon, or poses a significant risk to, the natural resources of the seabed and subsoil in the JMA'.

At the 6th (2019) SIOFA Meeting of the Parties (MoP), Mauritius initially suggested that the horizontal overlap between the JMA and the SIOFA Area which consists of high seas only - meant that 'SIOFA can no longer devise any policy or implement any project in the' JMA, but subsequently indicated that this position might require reconsideration. ${ }^{110}$ At the same meeting, Mauritius also asserted that it has 'historic/traditional fishing rights' on the Saya de Malha Bank, ${ }^{111}$ which is a part of the JMA where significant fishing

\footnotetext{
106 Unnumbered working paper on file with author.

107 NEAFC WG VME 2018 (n 99), at p. 2.

108 Southern Indian Ocean Fisheries Agreement (Rome, 7 July 2006, in force 21 June 2012) available at http://www.fao.org/legal [SIOFA].

109 Article 3(a) of the Treaty concerning the Joint Management of the Continental Shelf in the Mascarene Plateau Region between of the Government the Republic of Mauritius and the Government of the Republic of Seychelles (Vacoas, 13 March 2012, in force 18 June 2012) (2012) 79 Law of the Sea Bulletin 41. For a discussion see Mossop (n 93), at pp. 227-230.

110 SIOFA, Report of the Sixth Meeting of the Parties, 1-5 July 2019, agenda items 12.8 and 15 [Sixth Siofa MoP]. See also Doc MoP6-INFO-o5 Revi.

111 Sixth siofa MoP (n 110), paras 23(c), 203. Other siofa reports use different terminology, for instance historical rights (e.g., Report of the Third (2019) siofa Compliance Committee Meeting, paras 28-30 and the Report of the Fifth (2018) siofa MoP, paras

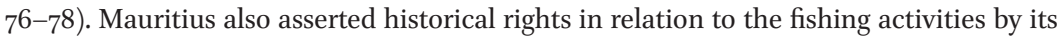
vessel Mariam 1 in May 2020.
} 
for demersal species occurs. ${ }^{112}$ The latter assertion may imply that Mauritius (and the Seychelles) is/are above all interested in getting exclusive or preferential access to these demersal species, rather than the conservation of benthic VMEs. A letter by the Joint Commission on the JMA shortly after the sixth MoP implicitly indicates that Mauritius and Seychelles do not have sovereign rights over non-sedentary species as target species, but is silent on their jurisdiction to protect the natural resources of the continental shelf against the impacts of fishing activities. ${ }^{113}$

Even though most of the other RFMOs and RFMAs (RFMO/As) with competence to regulate high seas bottom fishing to avoid adverse impacts on benthic VMEs have also actually exercised that competence, ${ }^{114}$ none of their constitutive instruments or relevant conservation and management measures give a role to coastal State members in relation to their continental shelves so-called 'subjacent coastal States' - or even acknowledge their sovereign rights. There are a variety of reasons for this. There may, for instance, be very limited or no outer continental shelves at all in the regulatory areas of RFMO/As. Also, in case outer continental shelves do exist, subjacent coastal State members may not be fully aware of the jurisdiction available to them. Alternatively, they may have no interest in exercising such jurisdiction, among other things, because this may require them to regulate bottom fishing in their AWNJ with equivalent stringency. Similarly, subjacent coastal State members may not be supportive of stringent regulation of high seas bottom trawling by RFMO/As on account of its impact on the vessels of such coastal States, especially in cases where fishing by vessels from other States is limited or absent. Juridical issues play a role as well, for instance the large number of unresolved

112 See, for example, the references to the Saya de Malha Bank in the Report of the Fifth (2018) SIOFA MoP.

113 Letter dated 5 September 2019 by the Joint Commission to the siofa Executive Secretary (on file with author).

114 This includes the Commission for the Conservation of Antarctic Marine Living Resources (CCAMLR) (which is 'more than an RFMo'), the General Fisheries Commission for the Mediterranean (GFCM), the Northwest Atlantic Fisheries Organization, the North Pacific Fisheries Commission, the South East Atlantic Fisheries Organisation and the South Pacific Regional Fisheries Management Organisation. In addition, there are three RFMAs that have such competence as well but have not exercised it so far; namely, (a) the CAOF Agreement (n 49), which has not yet entered into force; (b) the Convention on the Conservation and Management of Pollock Resources in the Central Bering Sea (Washington, DC, 16 June 1994, in force 8 December 1995) 34 ILM (1995), which does not have an active fishery at present; and (c) the Joint Norwegian Russian Fisheries Commission, which defers to NEAFC in this regard. 
maritime boundaries in the regulatory area of $\mathrm{GFCM}^{115}$ and the issue of title to Antarctic territory within the regulatory area of CCAMLR. ${ }^{116}$

For those RFMO/As that have deliberately avoided recognising the sovereign rights of subjacent coastal State members or giving such members a role in the regulation of high seas bottom fishing above their continental shelves, it may be argued that this is also unnecessary as long as such RFMO/As exercise their competence on bottom fishing consistent with applicable international obligations and requirements, and take account of the rights and interests of all their members in whatever capacity - including high seas bottom fishing States and subjacent coastal States - in the implementation of these obligations and requirements. According to such a view, their regulation of high seas bottom fishing above continental shelves illustrates that RFMO/As can also serve as vehicles to implicitly operationalise the mechanisms in Articles $78(2)$ and 116 (b) of the LOSC. Or, viewed differently, this can be one of their functions.

Regardless whether the absence of a role for subjacent coastal States members in the regulation of bottom fishing above outer continental shelves by $\mathrm{RFMO} /$ As has been deliberate or not, the question is how likely it is for such a role to be newly introduced. This depends first of all on the willingness of subjacent coastal State members to assert and advocate such a role. It seems that the extent of such willingness is strongly related to the composition of membership in RFMO/As in the context of the issue at hand - namely, the number and ratio of subjacent coastal State members vs high seas bottom fishing State members - as well as decision-making procedures and arrangements on adopting, extending, amending and withdrawing from existing conservation and management measures. The latter arrangements create default rules that determine if activities can either continue unless it is decided to prohibit or constrain them, or that activities can only commence after approval. In exceptionally asymmetrical scenarios - for instance where one single subjacent coastal State member is confronted by a block of high seas bottom fishing States members - it is highly unlikely that subjacent coastal States members will assert and advocate the abovementioned role, even if they would be dissatisfied with the overall performance of RFMO/As on high seas bottom fishing and the impact of such fishing on their continental shelves. Such exceptionally asymmetrical scenarios would be even more problematic at the global level.117

\footnotetext{
115 For the explanation of this acronym see (n 114).

116 Ibid. As regards sub-Antarctic islands, note that the understandings laid down in the Chairman's Statement included in the Final Act of the conference that adopted the Convention on the Conservation of Antarctic Marine Living Resources 'apply to waters adjacent to the islands', which does not necessarily comprise outer continental shelves.

117 See (n 181) and accompanying text.
} 


\section{Multilateral Creeping Coastal State Jurisdiction and the BBNJ Negotiations}

\section{Introduction}

The BBNJ negotiations were established in $2017^{118}$ and have so far led to a three-day organisational meeting in April 2018 and three substantive sessions. At the time of writing, no dates for the postponed fourth substantive session had been agreed. The origins of the BвNJ negotiations can be traced back to the establishment of the ввNJ Working Group ${ }^{119}$ in 2004. ${ }^{120}$ In 2015, the UNGA convened a Preparatory Committee (PrepCom) to develop substantive recommendations on the elements of a draft text for an international legally binding instrument. ${ }^{121}$ The PrepCom held four sessions in 2016 and $2017 .{ }^{122}$

Already at PrepCom 1, various delegations asserted special roles, interests and/or rights for adjacent coastal States. ${ }^{123}$ Such assertions were also made during the subsequent three PrepCom sessions - for instance a de facto veto for adjacent coastal States in relation to proposals for area-based management tools (А ВMTs) ${ }^{124}$ - leading other delegations to oppose such assertions. ${ }^{125}$ The Report of the PrepCom contains various references to adjacency in its Section A containing 'non-exclusive elements that generated convergence among most delegations.' ${ }^{26}$

Some coastal States are above all concerned about Авм Ts and marine protected areas (MPAs) in vertical (subjacency/superjacency) scenarios. They

118 See (n 9).

119 Formally titled, the Ad Hoc Open-ended Informal Working Group to study issues relating to the conservation and sustainable use of marine biological diversity beyond areas of national jurisdiction.

120 UNGA Res 59/24 (17 November 2004) Oceans and the law of the sea, Un Doc A/RES/59/24, para 73 .

121 UNGA Res 69/292 (19 June 2015) Development of an international legally binding instrument under the United Nations Convention on the Law of the Sea on the conservation and sustainable use of marine biological diversity of areas beyond national jurisdiction.

122 All relevant documentation on the вBNJ negotiations, the PrepCom and the вBNJ Working Group is available at https://www.un.org/bbnj/.

123 See the 'Chair's overview of the first session of the PrepCom', at pp. 10, 13, 15, 17.

124 See the 'Chair's streamlined non-paper on elements of a draft text of a [в BNJ Agreement]' prepared for PrepCom 3, at p. 23, para 107.

125 See Oude Elferink (n 84), at pp. 441-444; see also E Mendenhall et al., 'A soft treaty, hard to reach: The second inter-governmental conference for biodiversity beyond national jurisdiction' (2019) 108 Marine Policy 239-242; Mossop and Schofield (n 16), at pp. 1-2.

126 UNGA, Report of the Preparatory Committee, Fourth Session, un Doc A/AC.287/2017/PC.4/2 (31 July 2017), at para 38(a). References to adjacency appear at pp. 11-14. 
fear that ABMTS/M PAs and the concrete regulatory measures made applicable thereunder will interfere with the coastal States' ability to exercise their sovereign rights and jurisdiction over their continental shelves, in particular with regard to non-living resources. Iceland had such concerns when it realised that the original Charlie Gibbs Fracture Zone MPA proposal within the OSPAR Commission overlapped in part with its outer continental shelf submission to the Commission on the Limits of the Continental Shelf. ${ }^{127}$ The five other Arctic Ocean coastal States ${ }^{128}$ will have similar concerns, as almost the entire seabed below the four high seas pockets in the marine Arctic consists of outer continental shelves.

Some of the delegations advocating the notion of adjacency may have found inspiration or support in a policy brief on adjacency drafted by Dunn et al. ${ }^{129}$ prior to PrepCom 3. This policy brief argues that

so long as adjacent States can prove that their management measures conserve marine biodiversity within or beyond their national jurisdiction, the over-arching conservation mandate of [the LOSC] would support granting to those States greater influence over management of those ABNJ resources to which they lie adjacent. Under this approach, those qualified adjacent States would be allocated the primary responsibility to coordinate with existing sectoral and regional organizations to become the leading architects of new regional conservation agreements. ${ }^{130}$

Dunn et al. operationalise and expand the notion of adjacency by various forms of 'connectivity', namely ecological and cultural connectivity, with the former comprising a passive (or oceanographic) form and an active (or migratory) form. Their line of argumentation is inspired in particular by the preferential role accorded to coastal States in relation to anadromous and catadromous stocks and species pursuant to Articles 66 and 67 of the LOSC. ${ }^{131}$ In addition, they interpret the third preambular paragraph of the LOSC - 'Conscious that the problems of ocean space are closely interrelated and need to be considered

\footnotetext{
127 See Summary Record of the 2009 OSPAR Commission Meeting, at para 6.10.

128 Unlike Iceland, these five are central Arctic Ocean coastal States (see Molenaar 2019 (n 45), at p. 137).

129 DC Dunn et al., Adjacency: How legal precedent, ecological connectivity, and Traditional Knowledge inform our understanding of proximity, Nereus Scientific \& Technical Briefs on ABNJ series, policy brief prepared for PrepCom 3 (Nippon Foundation Nereus Program, Vancouver, April 2017), available at https://nereusprogram.org/reports.

130 Ibid., at p. 5 .

131 See the subsection 'Transboundary Stocks and Species'.
} 
as a whole' - as supporting their line of argumentation on connectivity. ${ }^{132}$ While a comparable interpretation has been included in the annual UNGA 'oceans' resolutions since $2005,{ }^{133}$ it is submitted that a more convincing view is that the preambular paragraph refers to the package-deal approach pursued during UNCLOS III. ${ }^{134}$ The propositions on connectivity have been developed further by Dunn and Harrison et al., ${ }^{135}$ and Popova et al. ${ }^{136}$ The First Draft includes 'ecological connectivity' as one of the indicative criteria for the identification of areas listed in Annex I, and some delegations have made proposals to include connectivity also elsewhere in the BBNJ Agreement. ${ }^{137}$ However, connectivity is not further operationalised in any of these instances, also not in relation to (adjacent) coastal States.

The discussion in this section continues with analysing relevant provisions included in the Preamble and Part I of the First Draft, entitled 'General Provisions'. Subsequently, the analysis focuses on the relevant provisions in Parts II-IV of the First Draft - which cover three of the four 'elements of the package' of the BBNJ negotiations - namely, marine genetic resources (MGRs), including questions on the sharing of benefits; measures such as ABMTs, including MPAs; and EIAs. The discussion then turns to Part VI of the First Draft, entitled 'Institutional Arrangements'.

\section{Preamble and General Provisions}

The First Draft's Preamble contains seven substantive paragraphs and its Part I contains six provisions, of which the second preambular paragraph ${ }^{138}$ and Articles 3(1), 4(1-3), 5 and 6 have relevance for the discussion here.

\footnotetext{
132 Dunn etal. (n 129), at p. 2.

133 UNGA Res 6o/3o (29 November 2005) Oceans and the law of the sea, UN Doc A/RES/6o/30, at p. 2.

134 Note the identical wording in the 'Declaration incorporating the 'Gentleman's Agreement' made by the President and endorsed by the Conference at its 19th meeting on 27 June 1974', appended to the Rules of Procedure for UnCLOS III (Un Doc A/CONF.62/3o/Rev.3). See also Oude Elferink (n 84), at p. 465 .

135 DC Dunn et al., 'The importance of migratory connectivity for global ocean policy' (2019) 286 Proceedings of the Royal Society B 20191472.

136 E Popova et al., 'Ecological connectivity between the areas beyond national jurisdiction and coastal waters: Safeguarding interests of coastal communities in developing countries' (2019) 104 Marine Policy 90-102.

137 See $\mathrm{n} 138$ and 158. Moreover, Indonesia invokes ecological connectivity in the context of impacts from ABNJ on archipelagic States (Compiled Textual Proposals Fourth BBNJ Session (n 12), at p. 399).

138 The Deep-Ocean Stewardship Initiative proposes a preambular paragraph on interconnectivity (Compiled Textual Proposals Fourth BBNJ Session (n 12), at pp. $5^{-6}$ ).
} 
Article 3(1) stipulates that the Agreement's geographical scope is limited to $\mathrm{ABNJ},{ }^{139}$ without requiring anything in relation to AWNJ. There may nevertheless be specific exceptions to this general rule in the 'package parts' of the BBNJ Agreement, for instance the obligation to conduct an EIA pursuant to Article 22(3) of the First Draft (see the subsection 'EIAs'). The approach pursued by Article 3(1) of the First Draft is very different from that pursued by Article 3 of the Fish Stocks Agreement, as it makes Articles $5^{-7}$ in their entirety also applicable to AWNJ. This latter approach cannot be easily transposed to the вBNJ Agreement, however, as the substantive issues and scenarios covered by it are very different from those covered by the вв NJ Agreement. At the same time, this difference does not preclude the BBNJ Agreement from prescribing tailor-made minimum requirements relating to AWNJ (e.g., compatible, complementary or similarly effective efforts, measures and procedures) for some of the package parts.

If the current text of Article 3(1) makes it to the final text unchanged, coastal States will not be subjected to new internationally agreed restraints on their sovereignty, sovereign rights and jurisdiction in AWNJ. It is submitted, however, that this does not necessarily imply that the BBNJ Agreement will actually ensure that regulation in $\mathrm{ABNJ}$ becomes more stringent than in $\mathrm{AWNJ}$, and that it thereby creates competitive advantages for coastal States. Such a determination requires not only an in-depth analysis of the package parts of the Agreement, but also of their implementation and application.

Article 4 of First Draft is entitled 'Relationship between this Agreement and the Convention and relevant legal instruments and frameworks and relevant global, regional, subregional and sectoral bodies'. Its paragraph 1 is identical to Article 4 of the Fish Stocks Agreement, which is cited and discussed in the subsection 'Post-U NCLOS III' above. Directly related to the second sentence of Article 4(1) of the First Draft is its second preambular paragraph, which reads 'Stressing the need to respect the balance of rights, obligations and interests set out in the Convention'. As argued in the subsection 'Post-UNCLOS III', however, these stipulations do not preclude the progressive development of the international law of the sea in cases where the LOsC does not address particular problems or issues at all, or only superficially or inadequately by means of a limited number of general provisions. Similarly, they do not preclude taking account of a range of developments since the adoption of the LOSC in 1982. It is therefore submitted that including new rights for adjacent coastal States in ABNJ and new mechanisms to address transboundary interactions between

139 See also $n 184$. 
$\mathrm{ABNJ}$ and $\mathrm{AWNJ}$ are not inconsistent with the second preambular paragraph and Article 4(1) per se, but can be justified in certain scenarios.

Paragraphs 2 and 3 of Article 4 read as follows:

2. The rights and jurisdiction of coastal States in all areas under national jurisdiction, including the continental shelf within and beyond 200 nautical miles and the exclusive economic zone, shall be respected in accordance with the Convention.

3. This Agreement shall be interpreted and applied in a manner that [respects the competences of and] does not undermine relevant legal instruments and frameworks and relevant global, regional, subregional and sectoral bodies.

Paragraph 2 is essentially a non-prejudice clause dedicated to coastal States that provides assurances in addition to those provided by the non-prejudice clause for all States included in the first sentence of paragraph 1 . Whereas its inclusion can, on the one hand, be regarded as creating a lack of even-handedness between coastal States and non-coastal States, on the other hand it can also provide a basis for justifiable further operationalisation in certain scenarios. This could be done elsewhere in the Agreement, by its institutions or by existing or new external bodies pursuant to a mandate accorded by, or guidelines adopted under, the Agreement. The not-undermining clause in paragraph 3 is aimed at achieving a result that is similar to a non-prejudice clause vis-àvis international instruments and frameworks and the competence of bodies established thereunder. ${ }^{140}$

Article 5 is entitled 'General [principles] [and] [approaches]' and consists of ten paragraphs containing principles or approaches. Even though the notion of adjacency is not included - neither explicitly nor implicitly - several paragraphs have direct or potential relevance, including the principle of equity (paragraph d), ecosystem and integrated approaches (paragraphs $\mathrm{f}$ and $\mathrm{g}$ ), the use of the best available science (paragraph i) and the 'non-transfer, directly

140 See, for instance, OSPAR Decision 2010/2 'on the establishment of the Charlie-Gibbs South Marine Protected Area', whose Article 2.2 stipulates: 'This Decision shall apply without prejudice to the rights and obligations of coastal States, other States and international organisations in accordance with [the LOSC] and customary international law'. See also Z Scanlon, 'The art of "not undermining": Possibilities within existing architecture to improve environmental protections in areas beyond national jurisdiction' (2018) 75 ICES Journal of Marine Science 405-416. 
or indirectly, of damage or hazards from one area to another' (paragraph j). ${ }^{141}$ All these paragraphs provide a basis for justifiable further operationalisation along the lines set out further above.

Article 6 is entitled 'International cooperation' and its paragraph 1 reads:

States Parties shall cooperate under this Agreement for the conservation and sustainable use of marine biological diversity of areas beyond national jurisdiction, including through strengthening and enhancing cooperation with and among relevant legal instruments and frameworks and relevant global, regional, subregional and sectoral bodies and members thereof in the achievement of the objective of this Agreement.

Whereas the first part of this single-sentence paragraph ('States ... jurisdiction') establishes a general obligation to cooperate, the second part specifies a wide range of scenarios on institutional and participatory relationships to which it extends. The First Draft further operationalises this obligation in many other provisions in the First Draft.

Reference should also be made to an Icelandic proposal to add a new paragraph 4 to Article $6 .{ }^{142}$ This proposal, which builds on an earlier proposal by Norway, ${ }^{143}$ focuses in particular on ABM TS and EIAs and ensures that decisionmaking on individual Авмтs or EIAs occurs only at the regional level. ${ }^{144}$ The proposal envisages critical roles for 'regional consultation processes' as well as regional bodies 'with a mandate to establish conservation and management measures to protect biodiversity from specific human activities in ABNJ'. For the latter - here referred to as regional ocean governance (ROG) bodies - the proposal uses wording that closely follows the wording in Article 8 of the Fish Stocks Agreement in relation to RFMOs. Where biodiversity in ABNJ in a region is under threat, the proposal requires relevant coastal States and States

141 OceanCare proposes an additional paragraph inspired by Article 194(2) of the LOSC (Compiled Textual Proposals Fourth BBNJ Session (n 12), at p. 51).

142 Compiled Textual Proposals Fourth вBNJ Session (n 12), at pp. 52-54.

143 Compiled Textual Proposals Third B BNJ Session (on file with author), at p. 8o.

144 See in this regard the alternatives in Articles 15(1) and (2), and 19(b) discussed in the subsection 'Measures such as ABMTs, including MPAs'. On the issue, see also AG Oude Elferink, 'Exploring the future of the institutional landscape of the oceans beyond national jurisdiction' (2019) 28 Review of European, Comparative and International Environmental Law 236-243; K Dalaker Kraabel, 'The ввNJ PrepCom and institutional arrangements: The hype about the hybrid approach' in MH Nordquist, JN Moore and R Long (eds), The Marine Environment and United Nations Sustainable Development Goal 14: Life Below Water (Brill/Nijhoff, Leiden, 2019) 137-172. 
operating in ABNJ to establish a ROG body. In case a ROG body already exists, States operating in $\mathrm{ABNJ}$ and relevant coastal States

shall give effect to their duty to cooperate by becoming members of such body or by agreeing to apply the conservation and management measures established by such body. States having a real interest in the activities concerned may become members of such body.

Similar to Article 8(3) of the Fish Stocks Agreement, if coastal States have a duty to cooperate with RoG bodies it can be assumed that they have a real interest, and therefore a right to membership as well. The Icelandic proposal thus grants a new right to coastal States in ABNJ and would enable new ROG bodies to perform new or existing roles in addressing transboundary interactions between $\mathrm{ABNJ}$ and $\mathrm{AWNJ}$ that are not already addressed by existing ROG bodes, such as RFMOs. As the focus is in particular on ABMTs and EIAs, the proposal would at any rate envisage ROG bodies to perform a role in EIAs which can also serve as a mechanism to address transboundary interactions - and any transboundary issues that would arise in relation to the sector- or activity-specific Авмтs of such RoG bodies. Participation by coastal States in ROG bodies may also be desirable and necessary for reasons that are not related to transboundary issues, for instance knowledge, expertise, resources and logistics.

Notably absent from Part I is a single overarching provision and mechanism to address transboundary interactions between $\mathrm{ABNJ}$ and AWNJ or an even more overarching provision and mechanism that would cover this. Including such provisions and mechanisms would fill the gaps identified in this regard in the section 'Adjacency, Superjacency, Subjacency and ABNJ in the LOSC and the Fish Stocks Agreement'. In light of the fact that the spatial scope of the в BNJ Agreement is limited to ABNJ, however, it is unlikely that agreement can be reached on an overarching provision and mechanism that is fully reciprocal and benefits not only coastal States.

\section{Relevant Elements of the Package}

MGRs, including Questions on the Sharing of Benefits

The First Draft's Part II on MGRs, including questions on the sharing of benefits, contains eight provisions, of which Articles 9(2), 10(5) and 11(4)(c) have relevance for the discussion here. In addition, paragraph 9 of Article 1 contains two alternative definitions for the term MGRs. Both are entirely in brackets and read as follows: 
Alt. 1. "Marine genetic resources" means any material of marine plant, animal, microbial or other origin, [found in or] originating from areas beyond national jurisdiction and containing functional units of heredity with actual or potential value of their genetic and biochemical properties.

Alt. 2. "Marine genetic resources" means marine genetic material of actual or potential value.

The delegations to the BвNJ negotiations seem to have a preference for alternative $2 .{ }^{145}$ The inclusion of a specification of the spatial scope in alternative 1 is somewhat unusual for a definition and seems more appropriate for Article 8, entitled 'Application'. Judging by the large number of brackets and proposals by delegations, however, agreement on Article 8 is probably still far ahead. It is also worth noting that it is not always clear if resources are part of ABNJ or AWNJ; for instance, resources such as mussels in brine pools on the seabed of the continental shelf subjacent to the high seas. ${ }^{146}$

Article 9 is entitled 'Activities with respect to [MGRs of ABNJ]'. Its paragraph 2 is entirely bracketed and reads:

In cases where marine genetic resources of areas beyond national jurisdiction are also found in areas within national jurisdiction, activities with respect to those resources shall be conducted with due regard for the rights and legitimate interests of any coastal State under the jurisdiction of which such resources are found.

This provision contains a one-sided obligation of due regard that benefits only coastal States, and that is operationalised further in Article 10(5). As is also reflected by the absence of any references to the notion of adjacency, the obligation's underlying rationale is not based on the transboundary nature of resources or impacts but on the mere location of MGRs. Quite strikingly, the obligation also applies when MGRs are found first, or discovered, in ABNJ and are subsequently also found in AWNJ. This preferential treatment accorded to coastal States not only challenges the first come, first served nature of the freedom of the high seas and international intellectual property law, but also

145 Compiled Textual Proposals Fourth B BNJ Session (n 12), at pp. 9-28.

146 See also J Mossop, "The relationship between the continental shelf regime and a new international instrument for protecting marine biodiversity in areas beyond national jurisdiction' (2018) 75 ICES Journal of Marine Science 444-45o, at p. 447; Mossop and Schofield (n 16), at p. 5 . 
the equitable distribution nature of the principle of the common heritage of mankind. Elements of the latter are also included in paragraph 4 of Article 9, which stipulates that the 'utilization of [MGRS of ABNJ] shall be for the benefit of mankind as a whole'. Arguably, paragraph 2 is not only inconsistent with paragraph 4, but also with Article 4(1). Applying Article 9(2) in practice will at any rate be problematic due to difficulties relating to the determination and verification of the location where MGRs are found, and the tracking and tracing of activities - a term not defined in the First Draft - that utilise MG Rs.

South Korea and United States propose deleting paragraph 2. ${ }^{147}$ Earlier, the Pacific Small Island Developing States proposed adding two new paragraphs after paragraph 2. ${ }^{148}$ The first requires prior consent by coastal States in certain circumstances and the second requires due regard for activities carried out in waters superjacent to outer continental shelves. The latter addresses the uncertainty that can exist as to whether resources are part of ABNJ or AWNJ. ${ }^{149}$ Except for its one-sidedness, this seems a reasonable proposition.

Article 10 is entitled '[Collection of] [and] [Access to] marine genetic resources of areas beyond national jurisdiction]. Its paragraph 5 is entirely in brackets and stipulates:

States Parties shall take the necessary legislative, administrative or policy measures, as appropriate, to ensure that activities with respect to marine genetic resources of areas beyond national jurisdiction that may result in the utilization of marine genetic resources found in areas both within and beyond national jurisdiction are subject to the prior notification and consultation of the coastal States [and any other relevant State] concerned, with a view to avoiding infringement of the rights and legitimate interests of [that] [those] State[s].

This provision further operationalises Article 9(5), while maintaining its onesidedness and preferential treatment to coastal States. It requires States Parties that conduct activities with respect to MGRS of ABNJ to notify and consult coastal States in whose maritime zones these MG Rs are also found; thereby giving coastal States a corresponding right to be notified and consulted. The First Draft no longer contains the alternative of prior consent that was still included in brackets in the Zero Draft. Indonesia proposes re-inserting prior consent. ${ }^{150}$

147 Compiled Textual Proposals Fourth вBNJ Session (n 12), at pp. 72-73.

148 Compiled Textual Proposals Third B BNJ Session (on file with author), at p. 113.

149 See (n 146) and accompanying text.

150 Compiled Textual Proposals Fourth B BNJ Session (n 12), at p. 77. 
The words 'may result in' create a very low threshold for the obligation of prior notification and consultation, and will probably be difficult to apply in practice, thereby acting as a disincentive for conducting activities with respect to MRGS in ABNJ. The process of prior notification and consultation is aimed at 'avoiding infringement of the rights and legitimate interests' of coastal States. This presumably signals that coastal States expect a share in the benefits arising from the utilisation of MGRS - also when they are found first in ABNJ - and it is by no means evident that they will be satisfied with the benefits set out in Article 11(4)(c), discussed below. South Korea and United States propose deleting paragraph $5 \cdot{ }^{151}$

Article 11 is entitled '[Fair and equitable] sharing of benefits]'. Paragraph 4 is entirely in brackets and contains a list of purposes for which benefits 'shared in accordance with this Part shall be used'. Subparagraph (c) reads as follows:

To build capacity to [collect] [access] and utilize marine genetic resources of areas beyond national jurisdiction [, including through common funding or pool funding for research cruises and collaboration in sample collection and data access where adjacent coastal States [shall] [may] be invited to participate, taking into account the varying economic circumstances of States that wish to participate];

The reference to adjacent coastal States is included in the second part starting with 'including through' - which is put in separate brackets. It relates to capacity-building through 'research cruises and collaboration in sample collection and data access', for which adjacent coastal States shall or may be invited to participate. The alternative 'shall' was newly introduced in the Zero Draft. The underlying rationale of this invitation could be research objects and objectives for which there are similarities or transboundary issues between ABNJ and AWNJ. In addition, participation by adjacent coastal States may offer them an opportunity to monitor compliance with the provisions of Part II in order to avoid infringement of their rights and interests in AWNJ. Whereas the European Union and its Member States, and South Korea propose deleting the second part of subparagraph 4 (c) and Israel paragraph 4 in its entirety, the United States opts for 'may and inserting 'voluntary' after 'including through'.152

In conclusion, the one-sided due regard obligation in Article 9(2) can be regarded as operationalising the non-prejudice clause in Article 4(2), and is in its turn operationalised further by means of the process of prior notification

\footnotetext{
151 Ibid., pp. 79, 81.

152 Ibid., pp. 89, 93, 95, 98.
} 
and consultation set out in Article 10(5). The current text does not give coastal States a right to withhold consent, and Part II contains no provisions on decision-making with regard to planned activities with respect to MGRs in ABNJ. Coastal States may nevertheless still have recourse to dispute settlement, assuming the final text of the BBNJ Agreement will provide for this. ${ }^{153}$ None of the provisions discussed above specifically focus on horizontal (adjacency) or vertical (subjacency/superjacency) scenarios or distinguish between them, even though the Pacific Small Island Developing States made a proposal in this regard. ${ }^{154}$ The chance for such proposals to end up in the final text may also not be that high. After all, except for a possible right to participate in research pursuant to Article 11(4)(c), the rights envisaged for coastal States pursuant to Articles 9(2) and 10(5) are not based on adjacency, but seek preferential treatment based on mere occurrence in AWNJ.

Measures such as ABMTs, including MPAs

Part III of the First Draft on measures such as ABM Ts, including MPAs, contains eight provisions of which Articles 14, 15(4) and (5), 17(4)(c) and (i), 18(2)(a)(iii) and (iv) and 19 have relevance for the discussion here. In addition, paragraphs 3 and 10 of Article 1 in Part I contain the following definitions for the terms ABMT and MPA:

3. "Area-based management tool" means a tool, including a marine protected area, for a geographically defined area through which one or several sectors or activities are managed with the aim of achieving particular conservation and sustainable use objectives [and affording higher protection than that provided in the surrounding areas].

10. "Marine protected area" means a geographically defined marine area that is designated and managed to achieve specific [long-term biodiversity] conservation and sustainable use objectives [and that affords higher protection than the surrounding areas].

The fact that ABMTs are defined to include MPAs means that MPAs are a subset of ABMTs. Or, in other words, all MPAs are ABMTs, but not all ABMTs are MPAS.

153 First Draft (n 10), Article 55; see Lijnzaad (n 10); J Mossop, 'Dispute settlement in the new treaty on marine biodiversity in areas beyond national jurisdiction' The NCLOS Blog (23 December 2019) available at https://site.uit.no/nclos/2019/12/23/dispute-settlement -in-the-new-treaty-on-marine-biodiversity-in-areas-beyond-national-jurisdiction.

154 See (n 148) and accompanying text. 
The most notable other difference between the two definitions is the phrase 'through which one or several sectors or activities are', which only appears in the definition of Авмт. This phrase and the fact that MPAs are a subset of ABMTs necessarily means that MPAs cannot be single-sectoral. However, the definitions do not clarify if MPAs must be cross-sectoral or holistic - thereby covering all sectors (e.g., fishing, shipping and mining) and activities - or if they can also be multi-sectoral.

Finally, both definitions contain bracketed wording at the end that ensures that ABMTS and MPAS only qualify as such when they afford 'higher protection' than the surrounding areas. This higher protection inside ABMTs and MPAS would then be afforded by regulatory measures that are more stringent than those in surrounding areas. As is also reflected in the dual objectives of conservation and sustainable use, increased stringency does not necessarily require complete prohibitions of activities, but can also be achieved by more limited restrictions. The underlying rationale of the bracketed wording would then seem to be that the ground for establishing ABMTs and MPAs must be to better protect that area by increasing the stringency of regulation therein. If that is indeed the understanding of delegations, the wording could be reformulated accordingly. ${ }^{155}$ Amendment is at any rate warranted because the current wording is problematic when the envisaged area is adjacent to areas in $\mathrm{ABNJ}$ or AWNJ where regulation already affords a similar or higher level of protection. ${ }^{156}$ If the bracketed wording is removed altogether - as several delegations propose $\mathrm{e}^{157}$ - this would mean that the ground for establishment could also be to have different but equally stringent regulations or - at least in theory - to have less stringent regulations.

Article 14 is entitled 'Objectives' and contains an exhaustive list of objectives relating to Part III. Several of its terms and phrases can potentially justify a role for adjacent coastal States, for instance 'holistic and cross-sectoral' (paragraph a), 'comprehensive system of [ABMTs, including MPAs]' (paragraph c), 'a system of ecologically representative [M PAs] that are connected' (paragraph d) and 'coherence and complementarity' (paragraph i). South Africa has proposed including the term connectivity as well. ${ }^{158}$

\footnotetext{
155 In relation to MPAs, the United States proposes replacing 'the surrounding areas' with 'would otherwise exist' (Compiled Textual Proposals Fourth BBNJ Session (n 12), at p. 20 ).

156 Ibid., at p. 17 for the observations by South Africa.

157 Ibid., at pp. 9, 11, 14-15, 19 and 21-23 for the proposals by the European Union and its Member States, Indonesia, Monaco, South Korea, United States (but only for ABMTs) and IUCN.

$15^{8}$ Ibid., at p. 126.
} 
Article 15 is entitled 'International cooperation and coordination'. The chapeau to paragraph 1 contains an obligation to 'promote coherence and complementarity in the establishment of [ABMTs, including MPAs]'. Subparagraphs (a) and (b), as well as an alternative in paragraph 2 , specify the ways in which that obligation is to be operationalised. The key choice here - and in Article 19(b) - is whether or not Part III will give the Conference of the Parties (COP) a mandate to adopt decisions on, or relating to, individual ABMTS or MPAs. ${ }^{159}$ Paragraphs 1 and 2 of Article 15 distinguish in this regard between, on the one hand, 'AвмTs, including MPAs', used together with 'established' and, on the other hand, 'conservation and [management] [sustainable use] measures', used together with 'adopted'. This distinction is likely to be inspired by, and consistent with, the distinction used by various regional and global bodies between, on the one hand, an overarching protective construct or concept that functions like a framework and, on the other hand, the concrete regulatory measures that constrain human activities that have been made applicable under that construct. One of the oldest examples in this regard is the IMo's construct of the Particularly Sensitive Sea Area (PSSA) and the associated protective measures made applicable thereunder. ${ }^{160}$

The First Draft contains no definitions for the terms 'measures' or 'conservation and [management] [sustainable use] measures'. As the envisaged measures would cover all sectors and activities, it would be appropriate to use generic wording that is sufficiently distinct from established wording for sector-specific measures, such as 'associated protected measures' connected to PSSAs used in the shipping sector and 'conservation and management measures' used in the fisheries sector. ${ }^{161}$

Some confusion in this terminology is nevertheless caused by the words 'measures such as' in the title of Part III, which lend themselves to the interpretation that Part III also deals with overarching protective constructs or concepts other than AвMTs and MPAs. Nothing in the text of Part III supports this interpretation, however. Even though this confusion could be simply avoided by deleting the relevant words, this may be difficult because they are part of

159 See in this regard the Icelandic proposal discussed in $\mathrm{n} 142$ and accompanying text.

16o See Iм0 Assembly Res A.982(24) (1 December 2005) Revised Guidelines for the Identification and Designation of Particularly Sensitive Sea Areas, Imo Doc A 24/Res.982, at para 1.2.

161 The Zero Draft consistently uses the term 'conservation and management measures' in Part III. As this term is not only consistently used in the Fish Stocks Agreement (n 54), but also defined in its Article 1(1)(b), some delegations in the ввNJ negotiations are likely to have proposed amendments that create a distinction with the terminology in the Fish Stocks Agreement. 
the carefully negotiated wording on the package-deal that paved the way for the вBNJ negotiations. ${ }^{162}$

Paragraph 4 of Article 15 reads:

Measures adopted in accordance with this Part shall not undermine the effectiveness of measures adopted by coastal States in adjacent areas within national jurisdiction and shall have due regard for the rights, duties and legitimate interests of all States, as reflected in relevant provisions of the Convention. Consultations shall be undertaken to this end, in accordance with the provisions of this Part.

This provision contains two separate mechanisms to address impacts of 'measures in accordance with this Part'; namely, a constraint to 'not undermine the effectiveness' for adjacent coastal States and a due regard constraint for all States. The due regard constraint also covers impacts on the rights, duties and legitimate interests of adjacent coastal States that would not be covered by the 'not undermine the effectiveness' constraint. Both mechanisms can be regarded as operationalisations of the non-prejudice clauses in paragraphs 1 and 2 of Article 4, and are further operationalised through the consultation process set out in Articles 17 and 18.

The mechanism for adjacent coastal States is one-sided as it only addresses transboundary impacts of ABNJ on AWNJ, but not vice versa. If this mechanism were to be made reciprocal, it would be applicable to AWNJ and thereby be an exception to the general rule on the spatial scope of the ввNJ Agreement. It seems unlikely that such an exception would attract the necessary support among delegations to the вBNJ negotiations, among other things, due to concerns that it may lead to more exceptions.

The mechanism applies to the interaction between 'measures adopted in accordance with this Part' and 'measures adopted by coastal States'. In light of the preceding discussion, it seems that the use of 'measures' in conjunction with 'adopted' is intended to denote concrete regulatory measures. Even though such measures must pursue at least one of the objectives laid down in Article 14, they can relate to any sector or activity and are not otherwise substantively delimited. Moreover, nothing in the First Draft suggests that measures should only be seen in terms of standard-setting and could not also relate to enforcement.

162 See Unga Res 66/231 (24 December 2011) Oceans and the law of the sea, UN Doc A/RES/66/231, at paras 166-167 and Annex, para (b). 
The mechanism consists of a constraint imposed on 'measures adopted in accordance with this Part' to ensure that these measures applicable to ABNJ do 'not undermine the effectiveness' of measures applicable to adjacent AWNJ adopted by coastal States. The words 'not undermine the effectiveness' are probably inspired by Article 7(2)(a) of the Fish Stocks Agreement, which uses the same words to operationalise the notion of compatibility. An example in the context of Article $7(2)(\mathrm{a})$ is when the total allowable catch (TAC) for the high seas component of a straddling or highly migratory fish stock is set at such a high level that it undermines the effectiveness of a coastal State's conservative, low-risk TAC for the stock's coastal component, with 'effectiveness' defined here as the extent to which it is able to avoid over-exploitation of the stock as a whole.

The question is, however, if an operationalised constraint for the fisheries sector is also suitable and appropriate for other sectors, as well as for multisector interactions. In order to answer this question, a better understanding of the 'measures scenarios' that could potentially arise is required. The fact that measures can relate to any sector or activity and are not otherwise substantively delimited, already leads to a very high number of scenarios if account is taken only of transboundary impacts of measures belonging to a single sector. The number of scenarios expands enormously if account is also taken of interaction between measures belonging to multiple sectors, for instance, the impact of a fisheries measure in ABNJ on a mining measure in AWNJ.

The necessary understanding of these scenarios could be obtained by identifying or mapping scenarios and other forms of scenario analysis. It may well be, however, that such scenario analysis cannot be carried out before the B BNJ negotiations are concluded. Under such circumstances, and the fact that the 'not undermine the effectiveness' constraint is a one-sided mechanism that only benefits coastal States, amendments to Article 15(4) are reasonable and justifiable, and should be considered. One amendment could consist of adding a qualification, for instance that all practicable and reasonable efforts shall be made to ensure that the effectiveness of coastal State measures is not undermined. Another amendment could take account of the sequence of the adoption of measures in light of the one-sidedness of the mechanism. Accordingly, the words 'previously agreed'163 or 'existing'164 could be inserted before 'measures adopted by coastal States'. The considerations underlying these proposed amendments are not addressed by the proposal by IUCN ${ }^{165}$

163 These words are also used in Article 7(2)(b) of the Fish Stocks Agreement (n 54).

164 This term is also used in Article 18(2)(a)(iii) of the First Draft ( $\mathrm{n} 10$ ).

165 See (n 14). 
to replace 'not undermine the effectiveness' with 'be compatible with and complementary to'. ${ }^{166}$

Despite the absence of a definition and any delimitation of the term 'measures', it is doubtful whether the 'not undermine the effectiveness' constraint protects coastal States from measures that interfere with their ability to exercise their sovereign rights and jurisdiction in adjacent AWNJ. Such protection is nevertheless provided by the non-prejudice clause in Article 4(2) and to some extent also by the due regard constraint in Article 15(4). As the risk of such interference exists in particular in vertical (subjacency/superjacency) scenarios, ${ }^{167}$ consideration could be given to amending Article 15(4) by including a cross-reference to Article 4(2) and highlighting the particular relevance of the vertical scenario.

Paragraph 5 of Article 15 reads as follows:

In cases where an area-based management tool, including a marine protected area, established under this Part subsequently falls under the national jurisdiction of a coastal State, either wholly or in part, it shall be adapted to cover any remaining area beyond national jurisdiction or otherwise cease to be in force.

This provision addresses the special scenario where coastal States have, for various reasons, not proclaimed EEzs or other $200 \mathrm{M}$ maritime zones, for instance many Mediterranean Sea coastal States. The words 'national jurisdiction' therefore relate only to the water column.

Article 17 is entitled 'Proposals' and deals with proposals for the establishment of АвMTs, including MPAs. Paragraph 4 contains a list of elements that proposals must 'at a minimum' include. The following two elements are related to adjacent coastal States:

(c) "Specific human activities in the area, including uses by indigenous peoples and local communities in adjacent coastal States;"

(i) "Information on any consultations undertaken with adjacent coastal States and/or relevant global, regional, subregional and sectoral bodies."

Subparagraph $4(\mathrm{i})$ is based on the consultation process required by Article 15(4), which implicitly imposes an obligation to consult for those that submit

166 Compiled Textual Proposals Fourth в BNJ Session (n 12), at pp. 154-155.

167 Mossop (n 146), at pp. 448-449. 
proposals for ABMTs, including MPAs, and implicitly grants others a right to be consulted. This obligation and its corresponding right presumably already apply in the phase before proposals are submitted (or pre-submission phase). Although the term 'any' in subparagraph 4(i) could be used to support a different interpretation, its purpose may also be to cover the scenario where there are simply no adjacent coastal States or relevant bodies.

The European Union and its Member States have proposed extensive amendments to Article 17(4)(i) that, inter alia, replace 'adjacent coastal States' with 'all States including the most potentially affected States, including any States with a continental shelf subjacent or maritime area adjacent to' the area that is the subject of the proposal, and States 'that carry out human activities, including economic activities' in the area. ${ }^{168}$ This not only makes adjacent coastal States merely the principal subset of the most potentially affected States, but also highlights the distinction between vertical and horizontal scenarios. Indonesia's proposal on Article 17(4)(i) appears to broaden the role of adjacent coastal States in the pre-submission phase, Monaco proposes replacing 'adjacent ... bodies' by 'all relevant stakeholders, if any', and South Korea proposes deleting 'adjacent'. 69

Article 18 is entitled 'Consultation on and assessment of proposals' and deals with the 'post-submission phase'. Paragraph 1 stipulates that consultations on submitted proposals 'shall be inclusive, transparent and open to all relevant stakeholders'. Paragraph 2 envisages a preliminary review of the initial proposal, which the proponent - or proponents - shall take into account before retransmitting the proposal. This would in most cases require at least some revision of the initial proposal. In the subsequent consultations, three groups of stakeholders are to be invited to submit their views and relevant information. Listed first in subparagraph (a) are 'States, in particular adjacent coastal States', who 'shall be invited to submit, inter alia':

(i) Views on the merits of the proposal;

(ii) Any relevant [additional] scientific inputs;

(iii) Information regarding any existing measures in adjacent areas within national jurisdiction;

168 Compiled Textual Proposals Fourth BBNJ Session (n 12), at pp. 153, 167. This proposal is similar to an earlier proposal by the European Union and its Member States (see Compiled Textual Proposals Third в BNJ Session (on file with author), at p. 275). Note also the similarities with the Icelandic proposal discussed in the text accompanying (n 142).

169 Compiled Textual Proposals Fourth в BNJ Session (n 12), pp. 154, 158-159. 
(iv) Views on the potential implications of the proposal for areas under national jurisdiction;

(v) Any other relevant information;

These views and information are to be made publicly available (paragraph 3 ) and shall be considered by the proponent, who must either revise the proposal or continue the consultation process (paragraph 4). The stipulation in paragraph 5 that 'the consultation period shall be time-bound' is a further indication that the proponent's obligation to consider the views and information submitted by stakeholders does not require it to ensure that the revised proposal is consistent with (all) submitted views or that it incorporates all submitted information. Paragraph 6 requires the proponent to submit the revised proposal to the Scientific and Technical Body, who will assess it and make recommendations on it to the COP. Paragraph 7 envisages further elaboration of the modalities of the consultation and assessment process, when necessary.

The European Union and its Member States propose an amendment to the chapeau of Article 18(2)(a) which is essentially similar to their proposed amendment to Article 17 (4)(i) discussed above. ${ }^{170}$ An earlier textual proposal by the Caribbean Community also highlighted the distinction between vertical and horizontal scenarios. ${ }^{171}$ Indonesia proposes adding 'and archipelagic States' after 'adjacent coastal States', and replacing 'for areas under national jurisdiction' in paragraph 2(a)(iv) with 'on the sovereign rights of coastal States in AWNJ 'including the continental shelf within and beyond 200 nautical miles and the [EEZ]. ${ }^{172}$ The proposals by Monaco and South Korea relating to Article 18 are similar to those relating to Article 17 discussed above. ${ }^{173}$ The Philippines proposes a new paragraph 6bis, which reads: 'In cases where the proposal affects areas of high seas that are surrounded by the [EEZs] of adjacent coastal states, the views and comments of such states shall be given particular regard'.174

Article 19 is entitled 'decision-making'. Apart from its chapeau, its text is entirely bracketed and includes two alternatives. The key issue is whether or not the COP will have a mandate to adopt decisions on, or relating to, individual AвмTs or MPAs. Such decisions could relate to the identification of areas requiring protection, the establishment of ABMTs or MPAs, and the adoption of concrete regulatory measures made applicable under АвмTs or M PAs.

170 Ibid., at p. 168; Compiled Textual Proposals Third ввNJ Session (on file with author), at p. 253 .

171 Compiled Textual Proposals Third вBNJ Session (on file with author), at p. 277.

172 Compiled Textual Proposals Fourth B BNJ Session (n 12), at p. 170.

173 Ibid., pp. 174, 176.

174 Ibid., p. 176. 
References to adjacency or coastal States are not included in Article 19 and neither are references to States in any other capacity. The proposals made during the PrepCom for a de facto veto for coastal States ${ }^{175}$ therefore did not attract the necessary support. In fact, whereas Article 19 of the Zero Draft still had its own decision-making rules - consensus decision-making combined with alternative rules to be developed by the COP - these have not been retained in the First Draft. This of course does not preclude the cop from adopting dedicated rules for decisions on, or relating to, individual ABMTS or MPAs at some time in the future anyway.

An important distinction made in Article 19 is that between the scenario in which there are 'relevant legal instruments or frameworks or relevant global, regional or sectoral bodies' and the scenario where these are absent. For this latter scenario, Japan proposes that the COP 'shall request relevant States, especially coastal States adjacent to the areas' for which ABMTs, including MPAs, are to be established, to choose one of two options: '(a) to establish such an instrument, framework or body to adopt and implement the decisions made by the [COP]; or (b) to entrust the [COP] to establish such [ABMTs, including MPAs], provided that all the relevant States agree to do so'.176 This proposal which has some similarities with the Icelandic proposal discussed above ${ }^{177}$ would give a de facto veto to all relevant States, including adjacent coastal States.

The Japanese proposal is focused on the level at which decisions on ABMTS and MPAs should be made, rather than on decision-making on individual ABMTs, MPAs or concrete regulatory measures made applicable thereunder. Regarding the latter, the question is if a role for coastal States is justifiable. As is argued above, this depends above all on the measures scenario at hand. In scenarios where coastal States have already adopted measures for AWNJ whose effectiveness depends on measures adopted for $\mathrm{ABNJ}$, it appears justifiable to give them a distinct - but not preferential - role in decision-making. A preferential role may nevertheless be justifiable in vertical scenarios involving measures that could interfere with the ability of subjacent coastal States to exercise their sovereign rights and jurisdiction over their continental shelves. According such a role would operationalise Article 4(2) of the First Draft and Article $78(2)$ of the LOSC. In that regard, account could be taken of the ideas developed within the NEAFC Working Group on VMEs. ${ }^{178}$

175 See (n 124) and accompanying text.

176 Compiled Textual Proposals Fourth B BNJ Session (n 12), at p. 186.

177 See (n 142) and accompanying text.

178 Discussed in the subsection 'High Seas - Continental Shelf'. 
However, in case such operationalisation does not occur - neither in the вв NJ Agreement nor by its COP thereafter - subjacent coastal States would at least have recourse to dispute settlement; assuming the final text of the BвNJ Agreement will provide for this. The likelihood of this procedure to be used in the scenario at hand is nevertheless limited due to considerations similar to those that exist in exceptionally asymmetrical scenarios in RFMO/As, where a single coastal State would be opposed by a block of other States. ${ }^{179}$ Such asymmetrical scenarios would be even more problematic at the global level, as that could lead a single coastal State to find itself opposed by essentially the entire international community. One example of such a scenario is the procedure for the designation of archipelagic sea lanes laid down in Article 53 of the Losc. This procedure implies that archipelagic States cannot designate archipelagic sea lanes without first obtaining IMO approval, ${ }^{180}$ which essentially requires approval by the entire international community. The fact that this procedure has been used only once so far, by Indonesia, and merely led to a partial rather than a comprehensive designation, ${ }^{181}$ can be regarded as evidence of the shortcomings of exceptionally asymmetrical scenarios.

These concerns also exist for the BвNJ Agreement, and not just for adjacent coastal States. A single adjacent coastal State could find itself alone when confronted by an ABMT or M PA proposed by others. Proponents of ABMTS or M PAs - which can also be adjacent coastal States - will have similar concerns, as they take it upon themselves to develop a proposal and lead it through a very complex consultation procedure in which numerous hurdles can arise. This is aptly illustrated by the enormous difficulties encountered by CCAMLR members in securing consensus for their proposals for CCAMLR MPAs, despite their significant investments in time and resources. ${ }^{182}$ A relevant factor for the interactions between States under the BBNJ Agreement is likely to be whether a proposal is oriented more towards conservation and affording higher protection or more towards sustainable use and affording equal protection.

\section{EIAS}

Part IV of the First Draft is entitled EIAs - despite also covering strategic environmental assessments (SEAs) in Article 28 - and contains 21 provisions, of which Articles 22(3), 26, 34(2), (3) and (4), 38 and 41(3) have relevance for the

\footnotetext{
179 Ibid.

180 See LosC (n 3), Article 53(9).

181 IMO Resolution MSC.72(69) (19 May 1998) Adoption, designation and substitution of archipelagic sea lanes.

182 See the very limited progress documented in the reports of Annual CCAMLR Meetings during the last decade or so.
} 
discussion here. In addition, Article 1 in Part II contains the following two alternative definitions for the term EIA in paragraph 7 entirely in brackets:

7. Alt. 1. "Environmental impact assessment" means a process to evaluate the environmental impact of an activity [to be carried out in areas beyond national jurisdiction [, with an effect on areas within or beyond national jurisdiction]] [, taking into account [, inter alia,] interrelated [socioeconomic] [social and economic], cultural and human health impacts, both beneficial and adverse].

7. Alt. 2. "Environmental impact assessment" means a process for assessing the potential effects of planned activities, carried out in areas beyond national jurisdiction, under the jurisdiction or control of States Parties that may cause substantial pollution of or significant and harmful changes to the marine environment.

An EIA is defined as a process in both definitions. The different spatial scopes reflected in the definitions are discussed under Articles 22 and 26 below. The other significant difference relates to the types of impacts that will be assessed. Whereas alternative 2 confines the assessment to pollution and changes to the marine environment, acceptance of the bracketed text from 'taking into account' onwards in alternative 1 would broaden the assessment with various interrelated impacts. Various delegations in the ввNJ negotiations have indicated a preference for alternative 2, but none for the extended version of alternative $1 .{ }^{183}$

Article 22 is entitled 'Obligation to conduct [EIAs]' and its paragraph 3 reads:

The requirement in this Part to conduct an environmental impact assessment applies [only to activities conducted in areas beyond national jurisdiction] [to all activities that have an impact in areas beyond national jurisdiction].

The bracketed texts contain two alternatives for a general rule on the spatial scope of application of Part IV: occurrence of activities in ABNJ or occurrence of impacts in ABNJ. The first alternative excludes activities conducted in AWNJ, but covers impacts in AWNJ. The second alternative comprises activities in ABNJ as well as in AWNJ, but excludes impacts in AWNJ. The two alternatives are also reflected in bracketed text elsewhere in the First Draft, for instance in

183 Compiled Textual Proposals Fourth B BNJ Session (n 12), at pp. 9-28. 
the alternative definitions for the term EIA in Article 1(7) and the bracketed text 'with impacts' in many other provisions in Part IV, including Article 28 on SEAs. The first alternative is clearly preferable for coastal States and may also be the most likely choice in light of the support it appears to attract. ${ }^{184}$

Article $\mathbf{2 6}$ is entitled 'Transboundary impacts' and reads:

1. Possible transboundary impacts shall be taken into account in environmental impact assessments.

2. Where relevant, the environmental impact assessment process shall also take into account possible impacts in [adjacent] [coastal States] [areas within national jurisdiction, including the continental shelf beyond 200 nautical miles].

As the geographical scope of transboundary impacts is determined by the choice between the two alternatives in Article 22(3), redrafting Article 26 will eventually be necessary to ensure consistency between them. ${ }^{185}$ If the second alternative in Article 22(3) is chosen, the current text of Article 26(2) would also extend to possible impacts in AWNJ of one (adjacent) coastal State caused by activities undertaken in AWNJ of another (adjacent) coastal State. If, as seems more likely, the first alternative in Article 22(3) is chosen, Articles $22(3)$ and 26 would create a one-sided mechanism to address transboundary impacts that only constrains rights in ABNJ. Such a mechanism could be regarded as an operationalisation of the non-prejudice clause in Article 4(2). It would consist of an obligation to take into account possible impacts in AWNJ as part of the obligation to conduct an EIA pursuant to Article 22(1). In light of the mechanism's one-sidedness, it should be noted that coastal States are already constrained by general obligations to conduct an EIA for activities with possible impacts on ABNJ pursuant to Articles 194(2) and 206 of the LOSC, as well as customary international law, as recognised by international courts and tribunals. ${ }^{186}$

Part IV of the First Draft deals in separate provisions with different features and phases of the EIA process. Two of these provisions refer specifically to adjacent coastal States, namely Articles 34 and 41. Article 34 is entitled 'Public notification and consultation'. Its paragraphs $2-4$ read:

184 Ibid., at pp. 219-222 for the proposals by the European Union and its Member States, Indonesia, South Korea and the International Chamber of Shipping (ICS). Note that South Korea and the ICS also propose including 'activities' in Article 3(1) (Compiled Textual Proposals Fourth в BNJ Session (n 12), at pp. 33-34).

185 Ibid., at p. 245 for the proposal by the European Union and its Member States.

186 Mossop (n 146), at p. 446. 
2. Stakeholders in this process include potentially affected States, where those can be identified, [in particular adjacent coastal States] [, indigenous peoples and local communities with relevant traditional knowledge in adjacent coastal States,] relevant global, regional, subregional and sectoral bodies, non-governmental organizations, the general public, academia [, scientific experts] [, affected parties,] [adjacent communities and organizations that have special expertise or jurisdiction] [, interested and relevant stakeholders] [, and those with existing interests in an area].]

3. Public notification and consultation shall be transparent and inclusive [, and targeted and proactive when involving adjacent small island developing States].

4. [Substantive] comments received during the consultation process [from adjacent coastal States] shall be considered and [addressed] [responded to] by States Parties. States Parties shall give particular regard to comments concerning potential transboundary impacts. States Parties shall make public the comments received and the descriptions of how they were addressed.

The notion of adjacency appears in bracketed text in all three paragraphs. In addition to its use in relation to coastal States in paragraphs 2 and 4 as well as a specific group of coastal States in paragraph 3 - namely, small island developing States - it is also used in relation to indigenous peoples and local communities with relevant traditional knowledge, and communities and organisations that have special expertise or jurisdiction (paragraph 2). Acceptance of the bracketed text on adjacent coastal States in paragraph 2 would make them 'potentially affected States' and thereby give them the rights to be notified and consulted in the EIA process. Acceptance of the bracketed text in paragraph 3 would entitle small island developing States to targeted and proactive treatment during public notification and consultation. Paragraph 4 contains stipulations on comments made during the consultation process. Acceptance of the bracketed text on adjacent coastal States is unlikely as it would exclude comments by all other stakeholders. ${ }^{187}$ The interests of adjacent coastal States are nevertheless also recognised in the second sentence of paragraph 4 , which requires their comments to be given 'particular regard'.

Article $4 \mathbf{1}$ is entitled 'Review' and its entirely bracketed paragraph 3 reads:

187 Whereas the European Union and its Member States, and South Korea propose to delete the words, Indonesia proposes to delete the brackets (Compiled Textual Proposals Fourth BвNJ Session (n 12), pp. 265-266, 268). 
3. [All States and, in particular] Adjacent coastal States [, including small island developing States,] shall be [kept informed of] [consulted actively [, as appropriate,] in] the monitoring, reporting and review processes in respect of [an activity approved under this Agreement] [activities in areas beyond national jurisdiction].

This provision was newly introduced in the First Draft. As it is entirely bracketed and also contains many bracketed alternatives, it is highly uncertain how the final version will look like or if it even makes it to the final text. ${ }^{188}$ All that can be said is that it could lead to a right for adjacent coastal States to be informed or consulted in relation to authorised activities.

The provisions analysed above would create rights for adjacent coastal States within the EIA process on the ground that it would also serve as a mechanism to address transboundary interactions between ABNJ and AWNJ. These rights entitle adjacent coastal States to be notified and consulted for activities planned in ABNJ. Similar rights may be accorded in relation to monitoring, reporting and review once such activities have been authorised.

Article 38 on 'decision-making' contains no references to adjacency or coastal States, or to States in any other capacity; similar to Article 19 on decision-making in Part IV. Other similarities are that decision-making by the COP is merely one of two alternatives and that no decision-making rules are provided. The BBNJ Agreement may therefore not give the COP a mandate on decision-making in relation to EIAs. ${ }^{189}$

Similar to the First Draft's Part III on ABмTs discussed in the previous subsection, its Part IV on EIAs devotes no attention to various specific circumstances and scenarios involving adjacent coastal States. Neither Part III nor Part IV even highlight the distinction between horizontal (adjacency) and vertical (subjacency/superjacency) scenarios. Some delegations have made text proposals to ensure this in respect of Part III, but not in respect of Part IV. Many of the observations and suggestions made in the previous subsection on the usefulness and desirability of reflecting different scenarios relating to adjacent coastal States in the BвNJ Agreement, which would thereby further operationalise Article 4(2) of the First Draft and - in vertical (subjacency/ superjacency) scenarios - Article 78(2) of the LOSC, are also relevant for EIAs.

188 South Korea proposes deleting Article 41 in its entirety (Compiled Textual Proposals Fourth ввNJ Session (n 12), at p. 289).

189 The European Union and its Member States, and South Korea do not support decision-making by the cop (Compiled Textual Proposals Fourth ввNJ Session (n 12), at pp. 281-282). 
Of particular relevance for vertical scenarios is the fact that delegations to the ввлј negotiations seem to have a preference for the second alternative definition for EIA in Article 1(7). This would mean that the EIA process does not also cover impacts on the ability of subjacent coastal States to exercise their sovereign rights and jurisdiction over their continental shelves. Even though such coastal States may still be able to invoke the non-prejudice clause in Article 4(2), this does not give them a distinct or preferential role in decisionmaking by the COP; provided the COP is given a decision-making mandate at all. Instituting a dispute settlement procedure is not likely to be attractive for coastal States either. ${ }^{190}$

Additional scenarios that could be taken into account are the presence of adjacent or subjacent/superjacent areas that have been identified for their ecological or biological significance or vulnerability, ${ }^{191}$ or the possibility of cumulative impacts in light of activities undertaken in adjacent AWNJ. ${ }^{192}$

The observations on decision-making towards the end of the previous subsection are equally relevant for EIAs, including the risk of asymmetrical scenarios. As the underlying interests are different, however, the interactions between States are also likely to be different. Whereas the interests of a proponent of a proposal for an АВMT or MPA can be either more oriented towards conservation and affording higher protection or more towards sustainable use and affording equal protection, the interests of a State that is required to conduct an EIA are primarily utilisation-oriented. The default rule is also different. Activities undertaken in areas envisaged as ABMTS or MPAs can continue until ABMTS and MPAs are established and the concrete regulatory measures made applicable thereunder are adopted. Conversely, planned activities subject to an EIA can only commence after the EIA process has been completed and a decision has been made to allow the planned activity to proceed. This requirement of prior approval laid down in Article 38(2) can - despite the many exceptions to the obligation to conduct an EIA included in Article 23 - not only be regarded as a further operationalisation of Article 206 of the LOSC, but also as a progressive development of international law.

\section{Institutional Arrangements}

Part VI of the First Draft is entitled 'Institutional Arrangements' and consists of four provisions, of which only Article 48 has relevance for the discussion here. Article 48 is entitled 'Conference of the Parties' and consists of five paragraphs.

190 See (n 179) and accompanying text.

191 See First Draft (n 10), Articles 27(2), 30(2).

192 Ibid., Article 25. 
Decision-making is covered in paragraph 3 bis, which is entirely in brackets. It stipulates that, as a general rule, decisions by the COP are taken by consensus. Where consensus cannot be reached, decision-making will occur pursuant to a procedure adopted by the COP. References to adjacency or coastal States or to States in any other capacity are not included.

Paragraph 3ter is also entirely in brackets and reads:

Decisions of the Conference of the Parties shall be made publicly available by the secretariat and shall be transmitted to all States Parties in a timely manner, [in particular, to adjacent coastal States] as well as to relevant legal instruments and frameworks and relevant global, regional, subregional and sectoral bodies.

The bracketed reference to adjacent coastal States would require the Secretariat to devote special attention to ensuring that decisions are transmitted in a timely manner to these States. While this preferential treatment might have symbolic value for some delegations, its practical relevance is likely to be limited as the Secretariat will probably transmit decisions electronically to all States Parties at the same time. This may be why South Korea proposes to delete the bracketed phrase. ${ }^{193}$

\section{Conclusions}

The interrelated notions of adjacency and creeping coastal State jurisdiction have been a key driver in the historical development of the international law of the sea. General acceptance of adjacency as a basis for authority at sea paved the way for the post-World War II phase of unilateral coastal State claims to new and broader maritime zones. The LOSC managed to bring an end to this - the principal exception being Chile's Mar Presencial - but creeping coastal State jurisdiction per se continued, both unilaterally and multilaterally.

Multilateral creeping coastal State jurisdiction predominantly originates from intergovernmental bodies. In the post-LosC era, this phenomenon has manifested itself at the regional level - in particular by the rules and practices on participation, allocation of fishing opportunities and combating IUU fishing of several RFMOs - as well as at the global level - for instance through the Underwater Cultural Heritage Convention adopted under the auspices of UNESCO. Moreover, coastal States have had, and continue to have, a significant

193 Compiled Textual Proposals Fourth B BNJ Session (n 12), at p. 333. 
impact on the progressive development of the international law of the sea on account of their attempts and successes in confining such development to $\mathrm{ABNJ}$ and thereby avoiding internationally agreed restraints on their sovereignty, sovereign rights and jurisdiction in AWNJ.

The notions of adjacency, superjacency and subjacency have, in relation to ABNJ, been incorporated in the LOSC and the Fish Stocks Agreement through rights and mechanisms. Rights in ABNJ can be explicitly or implicitly granted to coastal States, or be tailored to them and their interests. The mechanisms address the transboundary impacts of activities, undertaken in ABNJ pursuant to the rights and jurisdiction of all States, on the sovereignty, sovereign rights, other rights and jurisdiction of coastal States in AWNJ, and/or vice versa. The purpose of these mechanisms is to protect or safeguard the various interests associated with the rights in $\mathrm{ABNJ}$ and AWNJ through substantive and procedural constraints, whether even-handed and reciprocal or not.

The LOSC does not have a single overarching provision and mechanism to address transboundary interactions between $\mathrm{ABNJ}$ and AWNJ. There are nevertheless four specific scenarios for which the LOSC and the Fish Stocks Agreement have such mechanisms. Three of these can be categorised as issueoriented - namely, transboundary stocks and species, deep seabed mining, and protection and preservation of the marine environment - and one as zoneoriented, namely, high seas waters superjacent to the continental shelf. Some of these mechanisms are further operationalised, for instance on straddling and highly migratory fish stocks by means of the Fish Stocks Agreement. The indispensable role of RFMOs in such mechanisms is one of the primary functions of such organisations. The right accorded to coastal States pursuant to Article 8(3) of the Fish Stocks Agreement to become members of such RFMOs is not just a logical corollary of this role, but an essential prerequisite for the proper functioning of the mechanism.

The vertical scenario of the high seas and the subjacent continental shelf is governed by multiple mechanisms laid down in the LOsc. The need for further operationalisation of the mechanisms in Articles 78(2) and 116(b) has arisen in particular in relation to high seas bottom fisheries that can cause significant adverse impacts on vulnerable marine ecosystems located on subjacent continental shelves. The only attempt in this respect seems to have occurred in the North-East Atlantic Fisheries Commission during 2018-2019. It failed due to concerns for precedent-setting effects for other RFMO/As and the B BNJ negotiations.

Assertions of special roles, interests and/or rights for adjacent coastal States were already made during the PrepCom phase (2015-2017) preceding 
the currently ongoing вBNJ negotiations. Some of these assertions have been transposed in the most recent draft text of the BвNJ Agreement dated 18 November 2019 (First Draft). Among the notable features in this respect that are included in the Preamble and Part I is Article 3(1), which limits the Bв NJ Agreement's geographical scope to $\mathrm{ABNJ}$, but does not require anything in relation to AWNJ. If the current text of Article 3(1) makes it to the final text unchanged, coastal States will therefore not be subjected to new internationally agreed restraints on their sovereignty, sovereign rights and jurisdiction in AWNJ. Another notable feature is the need for consistency with the LOSC, pursuant to the Preamble and Article 4(1). It is nevertheless submitted that this does not preclude progressive development of the international law of the sea and that new rights for adjacent coastal States in ABNJ and new mechanisms to address transboundary interactions between $\mathrm{ABNJ}$ and AWNJ can be justified in certain scenarios.

The non-prejudice clause dedicated to coastal States in Article 4(2) is in particular operationalised in three of the package parts of the Agreement, namely,

- Part II on MGRs, by a mechanism that consists of an obligation of due regard, and is operationalised further by a process of prior notification and consultation;

- Part III on ABMTs/M PAs by a mechanism that consists of a 'not undermine the effectiveness' constraint, and is operationalised further by a process of consultation; and

- Part IV on EIAs, by a mechanism that consists of an obligation to conduct an EIA, and is operationalised further by the EIA process.

In all these instances, coastal States are provided with rights to be notified and/ or consulted but not a right to withhold consent, despite various proposals by delegations in this regard. The provisions on decision-making in the Parts on ABMTS/MPAs, EIAS, and institutional arrangements contain no references to adjacency or coastal States, or States in any other capacity. It is also by no means certain that the COP under the BBNJ Agreement will have a mandate on decision-making on individual ABM TS, M PAs, concrete regulatory measures made applicable thereunder, or EIAs. Coastal States may nevertheless still have recourse to dispute settlement, assuming the final text of the BBNJ Agreement will provide for this.

The basis of the abovementioned mechanisms and their associated rights is not identical. Whereas they are based on adjacency for ABMTs/MPAs and EIAs, this is only marginally so for MGRs. Rather, the latter are mainly based on the location of MGRs in AWNJ, also when MGRs are found first in ABNJ. This 
preferential treatment accorded to coastal States not only challenges the first come, first served nature of the freedom of the high seas and international intellectual property law but also the equitable distribution nature of the principle of the common heritage of mankind. If maintained, this treatment would arguably be inconsistent with Article 4(1). Also, it would add a new dimension to creeping coastal State jurisdiction as it could be regarded as recognition that the rights of coastal States in AWNJ can be superior to the rights of all States as well as the interests of the international community in ABNJ. This could lead to other and broader assertions of such supremacy.

A lack of even-handedness is also a problem with the mechanisms for ABMTS/MPAs and EIAs. This is directly related to the restriction of the BBNJ Agreement's spatial scope to ABNJ, pursuant to Article 3(1). For EIAs this still depends on the choice between the two alternatives in the current text of Article 22. The broadest support seems to exist for alternative 1, which would establish an obligation to conduct an EIA only for activities conducted in ABNJ, with coverage including impacts in AWNJ. If alternative 1 is chosen, the mechanisms relating to ABMTS/M PAS and EIAs will be entirely one-sided and beneficial only to coastal States. In addition, this one-sidedness means that coastal States and AWNJ are exempt from the restrictions and obligations imposed on non-coastal States and ABNJ by the BBNJ Agreement.

The reasonableness and justifiability of the 'not undermine the effectiveness' constraint for ABMTs/MPAs also depends on a better understanding of the different scenarios that could potentially arise. It may well be that the identification or mapping of scenarios and other forms of scenario analysis cannot be carried out before the BBNJ negotiations are concluded. Under such circumstances, and the fact that the 'not undermine the effectiveness' constraint is a one-sided mechanism that only benefits coastal States, amendments to Article 15(4) are reasonable and justifiable, and should be considered.

For ABMTS/MPAs as well as EIAs, further attention should be devoted to distinguishing and further operationalising horizontal (adjacency) and vertical (subjacency/superjacency) scenarios. This should also cover decision-making in exceptionally asymmetrical scenarios, where a single (coastal) State could find itself opposed by a large block of other States, or even essentially the entire international community. The reality is, however, that agreement must first be reached on whether or not to give the COP a mandate on decision-making on individual ABMTS, MPAs, concrete regulatory measures made applicable thereunder, and EIAs. In case such a mandate is granted but insufficient time exists to develop tailored decision-making rules during the BвNJ negotiations, this task would be left to the COP. If such a mandate is not granted, however, that task will remain with regional and sectoral bodies. The cop could then 
still perform a useful role by providing guidance to such bodies by means of legally binding or non-legally binding global minimum standards. This would contribute to the uniformity of practice on issues of adjacency, subjacency/ superjacency and $\mathrm{ABNJ}$ and also assist in breaking deadlocks based on fears for precedent-setting effects. 